\title{
Guidelines for delineation of lymphatic clinical target volumes for high conformal radiotherapy: head and neck region
}

Hilke Vorwerk ${ }^{1,2^{*}}$ and Clemens F Hess ${ }^{1}$

\begin{abstract}
The success of radiotherapy depends on the accurate delineation of the clinical target volume. The delineation of the lymph node regions has most impact, especially for tumors in the head and neck region. The purpose of this article was the development an atlas for the delineation of the clinical target volume for patients, who should receive radiotherapy for a tumor of the head and neck region. Literature was reviewed for localisations of the adjacent lymph node regions and their lymph drain in dependence of the tumor entity. On this basis the lymph node regions were contoured on transversal CT slices. The probability for involvement was reviewed and a recommendation for the delineation of the CTV was generated.
\end{abstract}

\section{Introduction}

The major problem in radiation treatment with IMRT technique is the failure to select and delineate the target accurately, especially in patients with head and neck cancer, in which a high risk of subclinical nodal disease exists. CT-based investigation is not sufficient to detect metastases smaller than one centimetre in diameter [1]. Since the lymph node status is the most important prognostic factor in patients with squamous cell cancer in the head and neck region, and due to the limitation of clinical staging, other factors, like histopathologic examinations, may help to predict metastatic lymph node involvement [1-3].

The lymphatic migration of tumor cells is usually stepwise and occurs in a predictable manner [4-6]. Detailed anatomical knowledge of the lymphatic network associated with each area of the body is essential to define all the sides in which the presence of metastatic nodes should be investigated and to delineate on a morphological basis the optimal target volume to be treated by high conformal radiotherapy [5,7]. An optimization of radiation techniques to maximize local tumor control and to minimize side effects in radiotherapy of head and neck tumors requires proper definition and

\footnotetext{
* Correspondence: h.vorwerk@med.uni-goettingen.de

${ }^{1}$ Radiotherapy and Radiooncology, University Hospital Göttingen, Robert-

Koch-Str. 40, 37073 Göttingen, Germany

Full list of author information is available at the end of the article
}

delineation guidelines for the clinical target volume (CTV). Most previous results are consensus guidelines from different physicians $[2,8,9]$.

The purpose of this article was to define the lymphatic CTV for the radiation treatment on a CT based atlas for tumors of the head and neck region to have a principle recipe for the delineation for clinical use. This atlas displays the clinically relevant nodal stations and their correlation with normal lymphatic pathways on a set of CT images.

\section{General anatomy}

The main nasal cavity includes the cavities of the interior nose between the vestibule of the nose and the Choana (Figure 1). The oral vestibule is located between the teeth and the lips and the cheek respectively. The alveolar process border the oral cavity lateral and ventral, whereas the velum and palatine border the oral cavity to the cranial side (Table 1 ). The caudal limit is the floor of the mouth. The pharynx is defined as the region of the combined respiratory and digestive system, which is located dorsal of the oral cavity and nasal cavity, incipient cranial at the skull base up to caudal at the beginning of the esophagus and the trachea. The pharynx is divided into three regions - nasopharynx, oropharynx and hypopharynx. The exact limits between these regions are not definitely defined. The nasopharynx is located at the cranial part of the pharynx and ends 


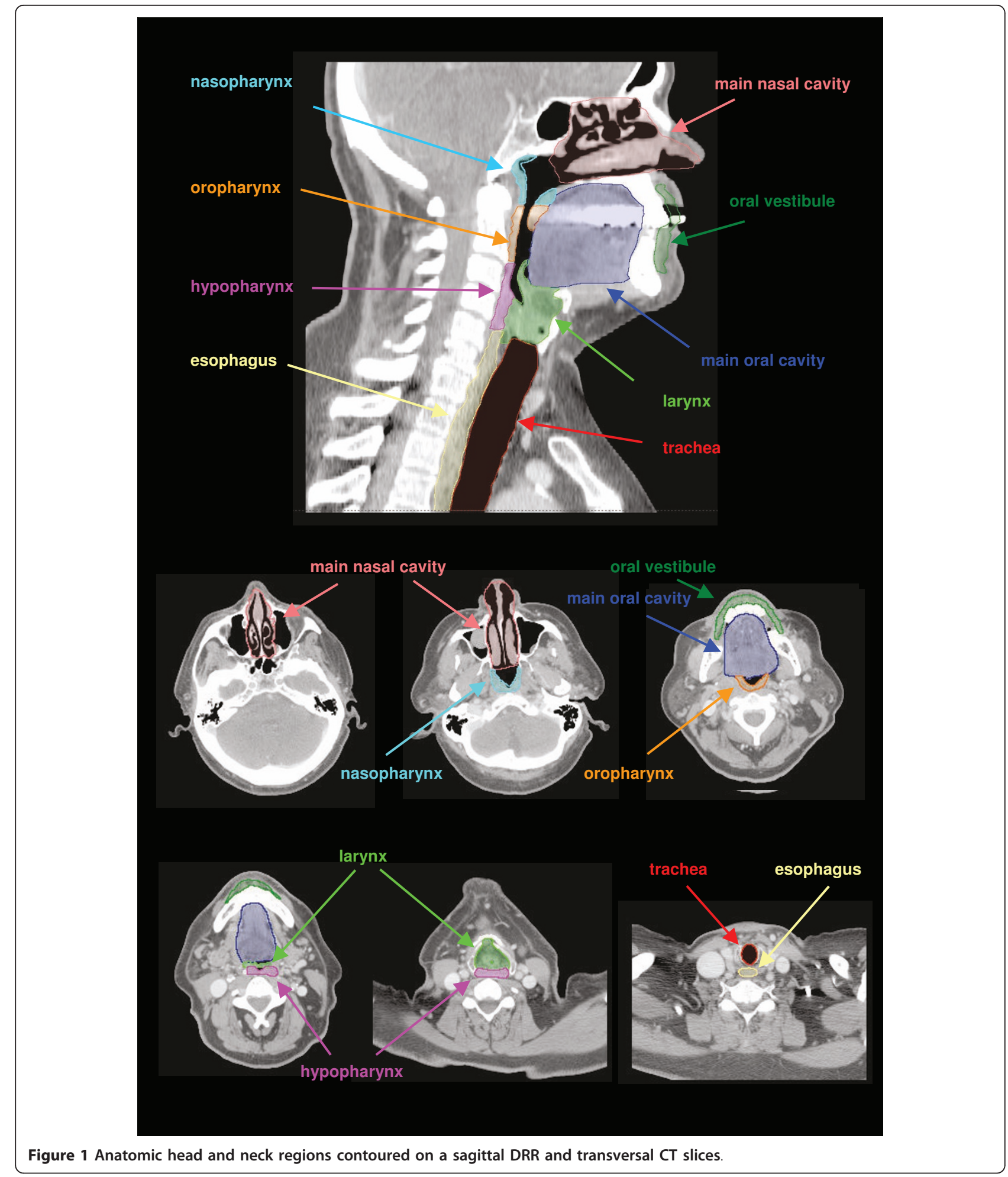

caudal at the velum palatinum. The nasopharynx includes the pharyngeal tonsil. The next section of the pharynx is the oropharynx, which ends at the top of the epiglottis. The third part of the pharynx is the hypopharynx, which begins cranial of the larynx and ends at the cranial ending of the cricoid cartilage behind the larynx. The larynx is subdivided into three parts: supraglottis, glottis and subglottis. The supraglottis is 
Table 1 Anatomic head and neck regions

\begin{tabular}{ll}
\hline anatomic region & description \\
\hline paranasal sinus & main nasal cavity \\
& vestibule of the nose \\
& maxillary sinus \\
\hline oral cavity & gingiva \\
& hard palate \\
& buccal mucosa \\
& floor of the mouth \\
& ventral 2/3 of the tongue \\
& oral vestibule \\
& lips \\
\hline salivary glands & parotid gland \\
& submandibular gland \\
& sublingual gland \\
\hline nasopharynx & $\begin{array}{l}\text { posterior wall of the pharynx beginning at the } \\
\text { threshold between the soft and hard palatine up to } \\
\text { the base of the skull } \\
\text { nasal surface of the soft palatine } \\
\text { palatine tonsil }\end{array}$ \\
\hline pharyngeal tonsil \\
arcus palatinus \\
root of the tongue \\
vallecula epiglottica \\
posterior wall of the oropharynx \\
oral surface of the soft palatine \\
uvula
\end{tabular}

the vestibulum of the larynx, beginning at the entrance of the larynx down to the fissure between the plicae vestibulares. The glottis is the intermediate cavity between the rima vestibule and the glottis opening. The most caudal laryngeal region down to the entrance of the trachea is the subglottis (infraglottic cavity).

\section{Lymph drainage}

The lymphatic CTV encompasses pathologic lymph nodes with a safety margin and adjacent areas, which are at risk for tumor spread. Lymph nodes should be assessed as pathologic, if their diameter is more than 1 $\mathrm{cm}$, all nodes with spherical rather than ellipsoidal shape, nodes containing inhomogeneities (suggestive of necrotic centers) or a cluster of three or more borderline nodes. In the node positive patients, an important factor to consider is the probability of capsular rupture and extracapsular extension. The lymphatic CTV do not only include lymph nodes (LN) with radiological criteria of involvement but also one or more adjacent lymph node regions $[2,10,11]$. The lymphatic drainage for each organ uses several pathways including the main collecting way, but also alternative routes [5]. These alternative routes should be included in the target volume definition in dependence of the feasibility for that route.

The anatomic patterns of lymphatic drainage for different body regions to their nodal stations were taken from Richter and Feyerabend Normal lymph node topography [12] and confirmed with other anatomy textbooks [5,13-15]. The elective irradiation of N0 patients can produce results equivalent to those obtained by neck dissection. Hence we used histopathologic analyses to create our suggested guidelines [16]. The main lymphatic routes for different organs, which are relevant in radiotherapy of the head and neck region, are summarized in Table 2. A general description of the anatomic lymph node drain for different lymph node regions can be found in Table 3 and Figure 2, 3, 4, 5, 6, 7, 8. The lymph node regions are classified into lymph node level (Table 4) adapted to Som et al. [17]. Guidelines for lymphatic CTV delineation of the most frequently cases of the different tumor entities were generated and summarized in Table 5,6,7,8.

\section{Lymph node level}

The main lymph node groups are classified analogically to Som et al. [17] into different levels (Table 4). The level IA contains the submental $\mathrm{LN}$ and the level IB the submandibular LN. The LN jugulares ( = LN cervicales laterales profundi) are subdivided in four groups - the LN ventrales jugulares superiores (level IIA), the LN dorsales jugulars superiores (level IIB), LN jugulares mediales (level III) and LN jugulares inferiores (level IV) (Figure 9, 10). We included the retrostyloid space, which range cranial to the scull base, analogically to Som et al. [17] in level IIA. There are only few data available about NM in the retrostyloid space, because a neck dissection do not extend beyond the posterior belly of digastric muscle [7]. Gregoire et al. 2006 [10] recommend to include the retrostyloid space in the CTV for nasopharyngeal cancer or NM in the caudal level II. For N0 patients there are not enough clinical data available to exclude this space from the CTV. The LN level IIB are localised dorsal of the LN level IIA, with the LN level IIA are near to the jugular vein and the LN level IIB are not attached to the jugular vein [17]. The caudal limit of the level IV is set to the clavicle [17]. The level $\mathrm{V}$ is divided into the LN cervicales posteriores profundi (level VA) cranial of the musculus omohyoideus and the LN supraclaviculares (level VB) 
Table 2 Anatomy - lymph node regions

\begin{tabular}{|c|c|c|c|c|c|}
\hline $\begin{array}{l}\text { anatomic } \\
\text { region }\end{array}$ & organ & subregion & 1. lymph node region & figure & 2. lymph node region \\
\hline \multirow[t]{2}{*}{ nasal cavity } & nose & anterior parts of the mucosa & LN submandibulares & 3 & $\begin{array}{l}\mathrm{LN} \text { ventrales jugulares } \\
\text { superiores }\end{array}$ \\
\hline & & posterior part of mucosa & $L N$ retropharyngeales & 5 & $\begin{array}{l}\mathrm{LN} \text { ventrales jugulares } \\
\text { superiores }\end{array}$ \\
\hline \multirow[t]{13}{*}{ oral cavity } & $\begin{array}{l}\text { oral } \\
\text { cavity }\end{array}$ & $\begin{array}{l}\text { buccal mucosa, outer part of alveolar } \\
\text { ridge }\end{array}$ & LN submandibulares & 3 & $\begin{array}{l}\mathrm{LN} \text { ventrales jugulares } \\
\text { superiores }\end{array}$ \\
\hline & & inner part of alveolar ridge & LN submandibulares & 3 & $\begin{array}{l}\mathrm{LN} \text { ventrales jugulares } \\
\text { superiores }\end{array}$ \\
\hline & & hard and soft palate & $L N$ retropharyngeales & 5 & $\begin{array}{l}\text { LN ventrales jugulares } \\
\text { superiores }\end{array}$ \\
\hline & & & (crossing the sides!) & 3 & \\
\hline & & gingiva of the front teeth of mandible & LN submandibulares & 3 & $\begin{array}{l}\mathrm{LN} \text { ventrales jugulares } \\
\text { superiores }\end{array}$ \\
\hline & & & LN submentales & 3 & $\begin{array}{l}\text { LN ventrales jugulares sup./ } \\
\text { LN submand. }\end{array}$ \\
\hline & & upper gingiva & LN submandibulares & 3 & $\begin{array}{l}\mathrm{LN} \text { ventrales jugulares } \\
\text { superiores }\end{array}$ \\
\hline & & & $L N$ retropharyngeales & 5 & $\begin{array}{l}\text { LN ventrales jugulares } \\
\text { superiores }\end{array}$ \\
\hline & & & (crossing the sides!) & 3 & \\
\hline & & other gingiva of mandible & LN submandibulares & 3 & $\begin{array}{l}\mathrm{LN} \text { ventrales jugulares } \\
\text { superiores }\end{array}$ \\
\hline & & Teeth & LN submandibulares & 3 & $\begin{array}{l}\mathrm{LN} \text { ventrales jugulares } \\
\text { superiores }\end{array}$ \\
\hline & & floor of the mouth & LN submandibulares & 3 & $\begin{array}{l}\mathrm{LN} \text { ventrales jugulares } \\
\text { superiores }\end{array}$ \\
\hline & & & LN submentales & 3 & $\begin{array}{l}\text { LN ventrales jugulares sup./ } \\
\text { LN submand }\end{array}$ \\
\hline \multirow[t]{5}{*}{ tongue } & & tip of tongue & LN submentales & 3 & $\begin{array}{l}\text { LN ventrales jugulares sup./ } \\
\text { LN submand. }\end{array}$ \\
\hline & & lateral part of tongue & LN submandibulares & 3 & $\begin{array}{l}\mathrm{LN} \text { ventrales jugulares } \\
\text { superiores }\end{array}$ \\
\hline & & central and posterior part of tongue & LN ventrales jugulares superiores & 3 & \\
\hline & & & LN jugulares mediales & 3 & \\
\hline & & all & (crossing the sides!) & & \\
\hline \multirow[t]{3}{*}{ nasopharynx } & & & $L N$ retropharyngeales & 5 & $\begin{array}{l}\mathrm{LN} \text { ventrales jugulares } \\
\text { superiores }\end{array}$ \\
\hline & & & LN ventrales jugulares superiores & 5 & \\
\hline & & & (crossing the sides!) & & \\
\hline \multirow[t]{4}{*}{ oropharynx } & & dorsal part of the oropharynx & $L N$ retropharyngeales & 5 & $\begin{array}{l}\mathrm{LN} \text { ventrales jugulares } \\
\text { superiores }\end{array}$ \\
\hline & & & LN ventrales jugulares superiores & 5 & \\
\hline & & other parts & LN submandibulares & 3 & $\begin{array}{l}\mathrm{LN} \text { ventrales jugulares } \\
\text { superiores }\end{array}$ \\
\hline & & & LN ventrales jugulares superiores & 3 & \\
\hline \multirow[t]{3}{*}{ hypopharynx } & & & LN jugulares mediales & & \\
\hline & & & LN paratracheales & 7 & $\begin{array}{l}\text { LN jugulares mediales and } \\
\text { inferiores }\end{array}$ \\
\hline & & & LN retropharyngeales (caudal part) & 5 & $\begin{array}{l}\text { LN ventrales jugulares } \\
\text { superiores }\end{array}$ \\
\hline \multirow[t]{4}{*}{$\operatorname{larynx}$} & & supraglottic region & LN ventrales jugulares superiores & 6 & \\
\hline & & & LN infrahyoidei & 6 & LN jugulares mediales \\
\hline & & glottic region & supraglottic region & 6 & \\
\hline & & & subglottic region & 6 & \\
\hline
\end{tabular}


Table 2 Anatomy - lymph node regions (Continued)

\begin{tabular}{|c|c|c|c|c|}
\hline & subglottic region & LN prelaryngeales & 6 & LN jugulares mediales \\
\hline & & LN pretracheal & 7 & $\begin{array}{l}\text { LN jugulares mediales and } \\
\text { inferiors }\end{array}$ \\
\hline & & LN paratracheales & 7 & $\begin{array}{l}\text { LN jugulares mediales and } \\
\text { inferiores }\end{array}$ \\
\hline & posterior part of larynx & LN paratracheales & 7 & $\begin{array}{l}\text { LN jugulares mediales and } \\
\text { inferiores }\end{array}$ \\
\hline & all & $\begin{array}{l}\text { crossing the sides! no crossing } \\
\text { between supraglottic and glottic } \\
\text { region }\end{array}$ & & \\
\hline ear & external auditory canal & LN parotidei profundi & 2 & $\begin{array}{l}\text { LN ventrales jugulares } \\
\text { superiores }\end{array}$ \\
\hline & tympanic cavity & LN parotidei profundi & 2 & $\begin{array}{l}\text { LN ventrales jugulares } \\
\text { superiores }\end{array}$ \\
\hline & & LN retropharyngeales & 5 & $\begin{array}{l}\text { LN ventrales jugulares } \\
\text { superiores }\end{array}$ \\
\hline & eustachian tube & LN retropharyngeales & 5 & $\begin{array}{l}\mathrm{LN} \text { ventrales jugulares } \\
\text { superiores }\end{array}$ \\
\hline orbit & cornea, sclera, lens, retina & - & & \\
\hline & conjunctiva & $\begin{array}{l}\text { circumferentially around cornea } \\
\text { [circulus lymphaticus] }\end{array}$ & & \\
\hline & lateral part of conjunctiva & LN parotidei profundi & 2 & $\begin{array}{l}\text { LN ventrales jugulares } \\
\text { superiores }\end{array}$ \\
\hline & & LN parotidei superficiales & 2 & $\begin{array}{l}\mathrm{LN} \text { ventrales jugulares } \\
\text { superiores }\end{array}$ \\
\hline & medial part of conjunctiva & LN faciales & 3 & LN submand. \\
\hline & & LN submandibulares & 3 & $\begin{array}{l}\text { LN ventrales jugulares } \\
\text { superiores }\end{array}$ \\
\hline paranasal & & LN ventrales jugulares superiores & & \\
\hline & & LN retropharyngeales & 5 & $\begin{array}{l}\text { LN ventrales jugulares } \\
\text { superiores }\end{array}$ \\
\hline $\begin{array}{l}\text { cellulae } \\
\text { mastoidei }\end{array}$ & & LN retroauricular [ = LN mastoidei] & 4 & $\begin{array}{l}\mathrm{LN} \text { ventrales jugulares } \\
\text { superiores }\end{array}$ \\
\hline $\begin{array}{l}\text { submandibular } \\
\text { gland }\end{array}$ & & LN submandibulares & 3 & $\begin{array}{l}\text { LN ventrales jugulares } \\
\text { superiores }\end{array}$ \\
\hline & & LN ventrales jugulares superiores & & \\
\hline parotid gland & cranial part & LN parotidei superficiales & 2 & $\begin{array}{l}\mathrm{LN} \text { ventrales jugulares } \\
\text { superiores }\end{array}$ \\
\hline & & LN parotidei profundi & 2 & $\begin{array}{l}\mathrm{LN} \text { ventrales jugulares } \\
\text { superiores }\end{array}$ \\
\hline & caudal part & LN parotidei superficiales & 2 & $\begin{array}{l}\mathrm{LN} \text { ventrales jugulares } \\
\text { superiores }\end{array}$ \\
\hline & & LN parotidei profundi & 2 & $\begin{array}{l}\text { LN ventrales jugulares } \\
\text { superiores }\end{array}$ \\
\hline & & LN cervicales laterales superficiales & 4 & LN cerv. prof. lat. mediales \\
\hline thyroid gland & medial superior part & LN pretracheal & 7 & $\begin{array}{l}\text { LN cerv. prof. lat. mediales } \\
\text { and inferiores }\end{array}$ \\
\hline & lateral superior part & LN jugulares mediales & 7 & \\
\hline & medial inferior part & LN pretracheal & 7 & $\begin{array}{l}\text { LN cerv. prof. lat. mediales } \\
\text { and inferiors }\end{array}$ \\
\hline & & LN paratracheal & 7 & $\begin{array}{l}\text { LN cerv. prof. lat. mediales } \\
\text { and inferiores }\end{array}$ \\
\hline & & LN thyroidei & & \\
\hline & lateral inferior part & LN jugulares inferiores & 7 & \\
\hline
\end{tabular}


Table 2 Anatomy - lymph node regions (Continued)

\begin{tabular}{|c|c|c|c|c|c|}
\hline \multirow[t]{29}{*}{ skin } & scalp & forehead & LN parotidei superficiales & 2 & $\begin{array}{l}\text { LN ventrales jugulares } \\
\text { superiores }\end{array}$ \\
\hline & & & LN submandibulares & 3 & $\begin{array}{l}\text { LN ventrales jugulares } \\
\text { superiores }\end{array}$ \\
\hline & & & LN faciales & 3 & LN submand. \\
\hline & & temple & LN parotidei superficiales & 2 & $\begin{array}{l}\text { LN ventrales jugulares } \\
\text { superiores }\end{array}$ \\
\hline & & region around the mastoid process & LN retroauricular [ = LN mastoidei] & 4 & $\begin{array}{l}\text { LN ventrales jugulares } \\
\text { superiores }\end{array}$ \\
\hline & & parietal part of the scalp & LN retroauricular [ = LN mastoidei] & 4 & $\begin{array}{l}\text { LN ventrales jugulares } \\
\text { superiores }\end{array}$ \\
\hline & & occipital scalp & LN occipitales & 4 & $\begin{array}{l}\text { LN dorsales jugulares } \\
\text { superiores }\end{array}$ \\
\hline & neck & nape & LN cervicales laterales superficiales & 4 & LN jugulares mediales \\
\hline & & side of the neck & LN cervicales posteriores profundi & 8 & LN supraclaviculares \\
\hline & & ventral part of neck & LN cervicales anteriores superficiales & 7 & LN pretracheal \\
\hline & & & & & LN paratracheales \\
\hline & & & & & LN jugulares inferiores \\
\hline & & $\begin{array}{l}\text { skin over sternocleidomastoid } \\
\text { muscle, supraclavicular, suprahyoidal, } \\
\text { infrahyoidal region }\end{array}$ & LN jugulares & & \\
\hline & face & lateral eyelid & LN parotidei superficiales & 2 & $\begin{array}{l}\text { LN ventrales jugulares } \\
\text { superiores }\end{array}$ \\
\hline & & & LN parotidei profundi & 2 & $\begin{array}{l}\text { LN ventrales jugulares } \\
\text { superiores }\end{array}$ \\
\hline & & medial eyelid & LN submandibulares & 3 & $\begin{array}{l}\text { LN ventrales jugulares } \\
\text { superiores }\end{array}$ \\
\hline & & & LN faciales & 3 & LN submand. \\
\hline & & lacrimal gland & LN parotidei profundi & 2 & $\begin{array}{l}\text { LN ventrales jugulares } \\
\text { superiores }\end{array}$ \\
\hline & & cheek & LN submandibulares & 3 & $\begin{array}{l}\text { LN ventrales jugulares } \\
\text { superiores }\end{array}$ \\
\hline & & lower lip & LN submentales & 3 & $\begin{array}{l}\text { LN ventrales jugulares sup./ } \\
\text { LN submand }\end{array}$ \\
\hline & & chin & LN submandibulares & 3 & $\begin{array}{l}\text { LN ventrales jugulares } \\
\text { superiores }\end{array}$ \\
\hline & & & (crossing the sides!) & & \\
\hline & & upper lip & LN submandibulares & 3 & $\begin{array}{l}\text { LN ventrales jugulares } \\
\text { superiores }\end{array}$ \\
\hline & nose & root of the nose & LN parotidei profundi & 2 & $\begin{array}{l}\text { LN ventrales jugulares } \\
\text { superiores }\end{array}$ \\
\hline & & other parts of the nose & LN submandibulares & 3 & $\begin{array}{l}\text { LN ventrales jugulares } \\
\text { superiores }\end{array}$ \\
\hline & & & LN faciales & 3 & LN submand. \\
\hline & ear & anterior part & LN parotidei superficiales & 2 & $\begin{array}{l}\text { LN ventrales jugulares } \\
\text { superiores }\end{array}$ \\
\hline & & lower part & LN cervicales laterales superficiales & 4 & LN jugulares mediales \\
\hline & & posterior part & LN retroauricular [ = LN mastoidei] & 4 & $\begin{array}{l}\text { LN ventrales jugulares } \\
\text { superiores }\end{array}$ \\
\hline
\end{tabular}


Table 3 Anatomy - lymph node drain

\begin{tabular}{|c|c|c|c|c|c|}
\hline $\begin{array}{l}\text { Lymph node } \\
\text { regions }\end{array}$ & Subgroups & Anatomic site & Influx & Efflux & Figure \\
\hline \multirow[t]{4}{*}{$\begin{array}{l}\text { LN parotidei } \\
\text { profundi }\end{array}$} & $\begin{array}{l}\mathrm{LN} \\
\text { preauriculares }\end{array}$ & ventral of the auricle & external auditory canal & $\begin{array}{l}\text { (partially over the LN parotidei } \\
\text { superficiales) }\end{array}$ & 2 \\
\hline & $\begin{array}{l}\mathrm{LN} \\
\text { intraparotidei }\end{array}$ & medial of the parotid gland & tympanic cavity & & \\
\hline & $\begin{array}{l}\text { LN } \\
\text { infraparotidei }\end{array}$ & dorsocaudal of the parotid gland & parotid gland & $\begin{array}{l}\text { to the } L N \text { ventrales jugulares } \\
\text { superiores }\end{array}$ & \\
\hline & & & $\begin{array}{l}\text { skin of the root of the nose, the } \\
\text { cheek, the lateral part of the } \\
\text { eyelid and conjunctiva }\end{array}$ & & \\
\hline \multicolumn{2}{|l|}{$\begin{array}{l}\text { LN parotidei } \\
\text { superficiales }\end{array}$} & on the fascia parotidea & $\begin{array}{l}\text { skin of the anterior part of the } \\
\text { ear, the forehead, the temple, } \\
\text { the lateral part of the eyelid and } \\
\text { conjunctiva }\end{array}$ & LN ventrales jugulares superiores & 2 \\
\hline \multicolumn{2}{|l|}{$\begin{array}{l}\mathrm{LN} \\
\text { retroauriculares ( } \\
=\mathrm{LN} \text { mastoidei) }\end{array}$} & lateral of the mastoid process & $\begin{array}{l}\text { skin of the posterior part of the } \\
\text { ear, the region around the } \\
\text { mastoid process, parietal part of } \\
\text { the scalp and from the cellulae } \\
\text { mastoideae. }\end{array}$ & LN ventrales jugulares superiores & 4 \\
\hline \multirow[t]{2}{*}{ LN occipitales } & & at the linea nuchae superior & skin at the occipital scalp & LN dorsal jugulares superiores & 4 \\
\hline & & & & $\begin{array}{l}\text { LN cervicales laterales } \\
\text { superficiales }\end{array}$ & \\
\hline \multirow[t]{4}{*}{ LN submentales } & & $\begin{array}{l}\text { ventral between the two venter } \\
\text { of the musculus digastricus }\end{array}$ & tip of tongue & LN submandibulares & 3 \\
\hline & & & floor of the mouth & LN ventrales jugulares superiores & \\
\hline & & & $\begin{array}{l}\text { laterals of the two front teeth of } \\
\text { the mandible }\end{array}$ & & \\
\hline & & & skin of the lower lip and chin & & \\
\hline \multirow[t]{3}{*}{$\begin{array}{l}\text { LN } \\
\text { submandibulares }\end{array}$} & & $\begin{array}{l}\text { adjacent to the submandibular } \\
\text { gland }\end{array}$ & anterior part of the nasal cavity & LN ventrales jugulares superiores & 3 \\
\hline & & & $\begin{array}{l}\text { skin/mucosa of the lips/cheek, } \\
\text { palate, teeth, gingiva, lateral } \\
\text { tongue and floor of the mouth }\end{array}$ & & \\
\hline & & & $\begin{array}{l}\text { skin from the forehead, nose } \\
\text { and the medial part of the } \\
\text { eyelid and the conjunctiva over } \\
\text { inconstant LN faciales (LN } \\
\text { buccales) }\end{array}$ & & \\
\hline \multicolumn{2}{|l|}{$\begin{array}{l}\text { LN facials } \\
\text { (inconstant) }\end{array}$} & arranged around the $\mathrm{V}$. angularis & $\begin{array}{l}\text { skin from the forehead, nose } \\
\text { and the medial part of the } \\
\text { eyelid and the conjunctiva }\end{array}$ & LN submandibulares & 3 \\
\hline \multicolumn{2}{|l|}{$\begin{array}{l}\text { LN dorsales } \\
\text { jugulares } \\
\text { superiores }\end{array}$} & $\begin{array}{l}\text { medial of the musculus } \\
\text { sternocleidomastoideus and } \\
\text { dorsal of the jugular vein }\end{array}$ & LN occipitales & LN ventrales jugulares superiores & 4 \\
\hline \multirow[t]{2}{*}{$\begin{array}{l}\text { LN cervicales } \\
\text { laterales } \\
\text { superficiales }\end{array}$} & & $\begin{array}{l}\text { along the external jugular vein, } \\
\text { lateral of the musculus } \\
\text { sternocleidomastoideus }\end{array}$ & lower part of the parotid gland & LN jugulares mediales & 4 \\
\hline & & & $\begin{array}{l}\text { skin of the caudal part of the } \\
\text { ear, the nape and lateral neck }\end{array}$ & & \\
\hline \multirow[t]{5}{*}{$\begin{array}{l}\mathrm{LN} \\
\text { retropharyngeales }\end{array}$} & & $\begin{array}{l}\text { in the space bounded anteriorly } \\
\text { by the pharyngeal constrictors } \\
\text { and posteriorly by the } \\
\text { prevertebral Fascia, cranially by } \\
\text { the base of the skull and caudally } \\
\text { to the os hyoideum ** }\end{array}$ & nasopharynx & $\begin{array}{l}\text { from cranial to caudal up to the } \\
\text { level of the os hyoideum or to } \\
\text { the lateral side into the } L N \\
\text { ventrales jugulares superiores }\end{array}$ & 5 \\
\hline & & & dorsal part of the oropharynx & & \\
\hline & & & soft palate & & \\
\hline & & & eustachian tube & & \\
\hline & & & tympanic cavity & & \\
\hline
\end{tabular}


Table 3 Anatomy - lymph node drain (Continued)

\begin{tabular}{|c|c|c|c|c|c|}
\hline & & & dorsal part of the nasal cavity & & \\
\hline \multirow{5}{*}{$\begin{array}{l}\text { LN cervicales } \\
\text { anteriores } \\
\text { profundi }\end{array}$} & $\begin{array}{l}\text { LN } \\
\text { infrahyoidei }\end{array}$ & $\begin{array}{l}\text { located on the membrane } \\
\text { hyoidea }\end{array}$ & cranial half of the larynx & LN jugulares mediales & $6-7$ \\
\hline & $\begin{array}{l}\text { LN } \\
\text { prelaryngeales }\end{array}$ & $\begin{array}{l}\text { on the ligamentum } \\
\text { cricothyroideum }\end{array}$ & caudal half of the larynx & & \\
\hline & $\begin{array}{l}\text { LN } \\
\text { pretracheales }\end{array}$ & at the veins thyroideae inferiors & caudal half of the larynx & $\begin{array}{l}\text { LN jugulares mediales and } \\
\text { inferiores }\end{array}$ & $6-7$ \\
\hline & $\begin{array}{l}\text { LN } \\
\text { paratracheales }\end{array}$ & ventral/laterodorsal of the trachea & thyroid gland & & \\
\hline & LN thyroidei & at the thyroidea & thyroid gland & $\begin{array}{l}\text { LN jugulares mediales and } \\
\text { inferiores }\end{array}$ & \\
\hline \multirow[t]{2}{*}{$\begin{array}{l}\text { LN cervicales } \\
\text { anteriores } \\
\text { superficiales }\end{array}$} & & $\begin{array}{l}\text { around the vein jugularis } \\
\text { anteriores }\end{array}$ & ventral skin of the neck & LN pre- or paratracheales & 7 \\
\hline & & & & LN jugulares inferiores & \\
\hline $\begin{array}{l}\text { LN cervicales } \\
\text { posteriores } \\
\text { profundi }\end{array}$ & & $\begin{array}{l}\text { in the neck region caudal of the } \\
\text { LN occipitales }\end{array}$ & neck region & LN supraclaviculares & 8 \\
\hline \multirow[t]{6}{*}{$\begin{array}{l}\text { LN } \\
\text { supraclaviculares }\end{array}$} & & $\begin{array}{l}\text { between the M. omohyoideus } \\
\text { and the clavicular }\end{array}$ & caudal neck & $\begin{array}{l}\text { sometimes over the venous } \\
\text { jugulo-subclavian confluent or } \\
\text { the thoracic duct on the left side } \\
\text { and the lymphatic duct on the } \\
\text { right side, to the angulus venosus } \\
{[13,14] \text {. }}\end{array}$ & 8 \\
\hline & & & pharynx region & & \\
\hline & & & trachea & & \\
\hline & & & esophagus & & \\
\hline & & & LN mediastinales anteriores & & \\
\hline & & & LN axillares profundi & & \\
\hline
\end{tabular}

**We defined the retropharyngeal level analogically to Grégoire et al. [7] and Feng et al. [27].

(Figure 8) $[18,19]$. The definition of "level V" varies much in the literature. For this reason we decided to follow a definition based on anatomic lymph node regions combined with the surgical and histopathological information, which follows mostly the definition of Rotterdam $[1,3,4,9,20,21]$. The anterior compartment between the both levels III and IV is called level VI and includes the LN cervicales anteriores superficiales and profundi. The main lymph drain flows from level II over level III and IV over the truncus lymphaticus jugularis and/or subclavius to the angulus venosus of the same side of the body (Figure 9, 10) [4]. The truncus can end directly in a vein or on the right side over a ductus lymphaticus dexter or on the left side over the truncus thoracicus. The lymph form level IA flows over level IB to level IIA and the lymph from level VA over level VB to the angulus venosus. Level VI drains to level III and IV. There are still more lymph node regions, which are not respected by the classification by Robbins et al. [19]. The parotidal level contains the LN parotidei superficiales and profundi and drain to level IIA just as well as the level retropharyngeal and level retroauricular, which contains the LN retropharyngeales and LN retroauriculares, respectively. The LN faciales are classified into the level buccales, which drain to the level IB. The level external jugular includes the LN cervicales laterales superficiales and has efflux to the level III.

\section{General selection and delineation of the lymphatic CTV}

The spread of head and neck tumors into cervical LN is rather consistent and follows predictable pathways, with increasing risk at each level, if the adjoining proximal level is involved [2]. The incidence of occult metastases in LN ranges between $20 \%$ and $50 \%$ and $\mathrm{NM}$ in $\mathrm{cN}+$ (metastatic involvement of $\mathrm{LN}$ via clinical assessment) patients ranges between $35 \%$ and $80 \%$ for all tumors of the oral cavity, pharyngeal and laryngeal tumors, except glottic tumors (0$15 \%$ occult metastases). This indicates the necessity to include the adjacent lymph node regions in the CTV.

Most parts of the head and neck region has rich lymph node vessels. But some sites, as the true vocal cord, the paranasal sinuses and the mediales ear, have only few or no lymphatic vessels at all [7]. Typically the lymph drain remains on one body side. Only some structures, like the soft palate, the base of tongue and 


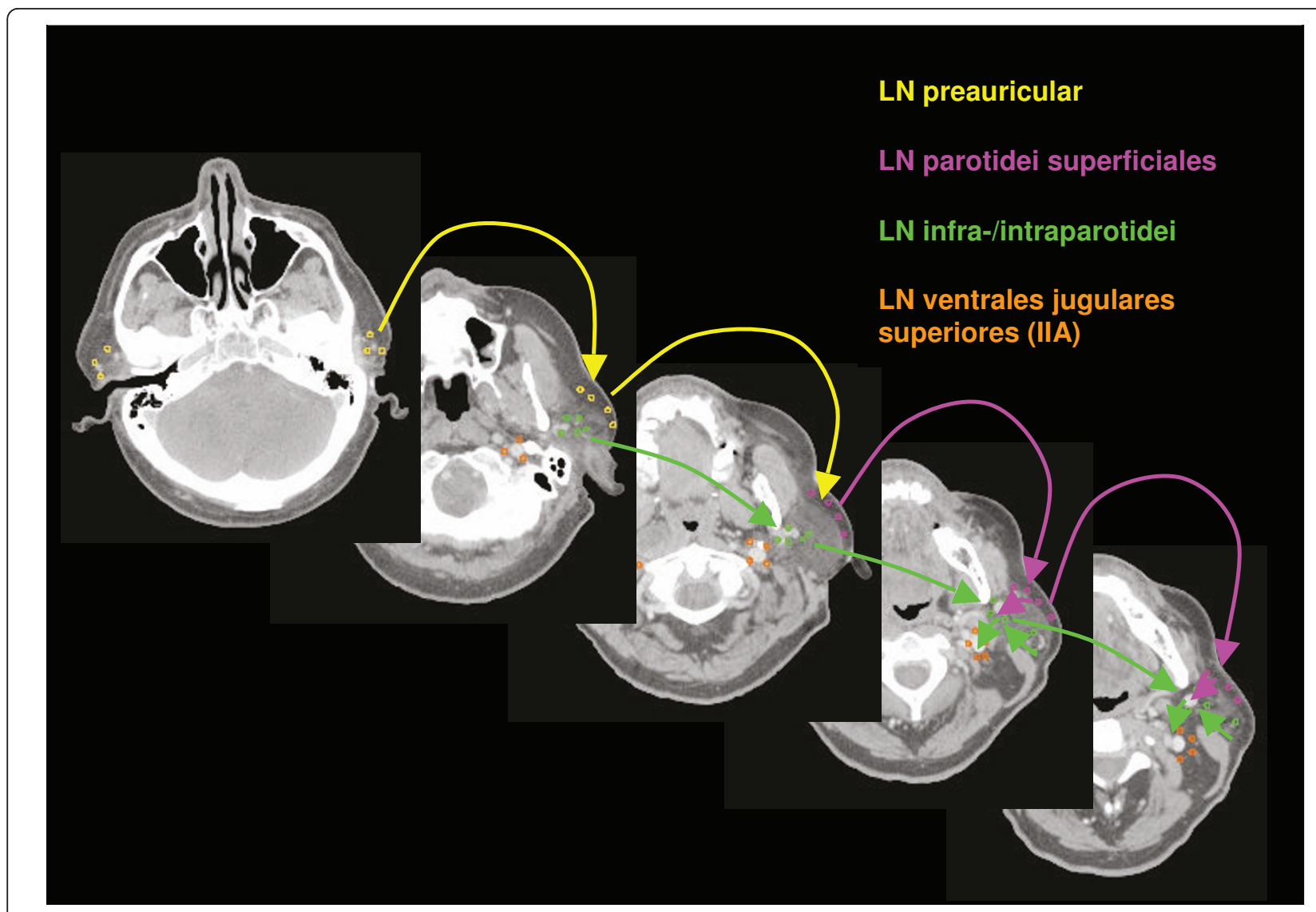

Figure 2 Lymph regions and drain contoured in transversal CT slices: LN parotidei superficiales (pink) and LN parotidei profundi subdivided into LN preauriculares (yellow) and LN infra-/intraparotidei (light green) [1.8 cm slice thickness].

the larynx have crossing lymph drain [7]. The retropharyngeal lymph vessel, which involving for example the lymph from the posterior pharyngeal wall and the nasopharynx, often cross the side.

The lymph drainage from the endolarynx takes different ways (Figure 6, Table 2). The supraglottic endolarynx drains through the membrana thyrohyoidea directly to the LN ventrales jugulares superiores (level IIA) or to the LN infrahyoidei and continuing to the LN jugulares mediales (level III). The lymph from the subglottic endolarynx flows through the ligamentum cricothyroideum to the LN prelaryngeales, LN pretracheales and LN paratracheales and further to the more caudal located LN lower jugulars (level IV). The glottis region of the endolarynx has only few lymph vessels, which are connected mostly to the upper endolarynx, but also to the lower endolarynx [6,12-14].

The distribution of pathologic confirmed NM depends on three major points - the clinical evaluation of the lymph node sides, the primary tumor side and tumor size [7].

- Patients with $\mathrm{cN}+$ have a much higher incidence of $\mathrm{NM}$ than patients with cNO (no metastatic involvement of LN via clinical assessment) [22]. Gregoire et al. [7] summarised the results from the Head and Neck Service at Memorial Sloan-Kettering Cancer Center between 1965 and 1989 with 33\% metastatic diseases in prophylactic neck dissections and $82 \%$ in therapeutic neck dissections. In patients, who underwent therapeutic neck dissection, the pattern of metastatic nodes was similar to the one observed in $\mathrm{cN} 0$ patients with one extra level of NM [7].

- Tumors of different anatomic locations in the head and neck region drain in different percentage to different lymph node level. In $\mathrm{cN}+$ patients Gregoire et al. 2000 described an incidence of metastatic disease in LN is highest in patients with nasopharyngeal cancer (80\%) and lowest in patients with tumors of the oral cavity (36\%). Patients with a laryngeal cancer have a much higher incidence of $\mathrm{NM}(54 \%)$ in contrast to cancer of the oral cavity, hypopharynx or oropharynx (17-25\%), if they have a T3-T4 stage tumor. And more cranial and anterior localised tumors mainly drain into the level I to III in contrast to more caudally located tumors, which mainly drain into level II to V. Nasopharyngeal and oropharyngeal tumors drain not only to the level IIA but 


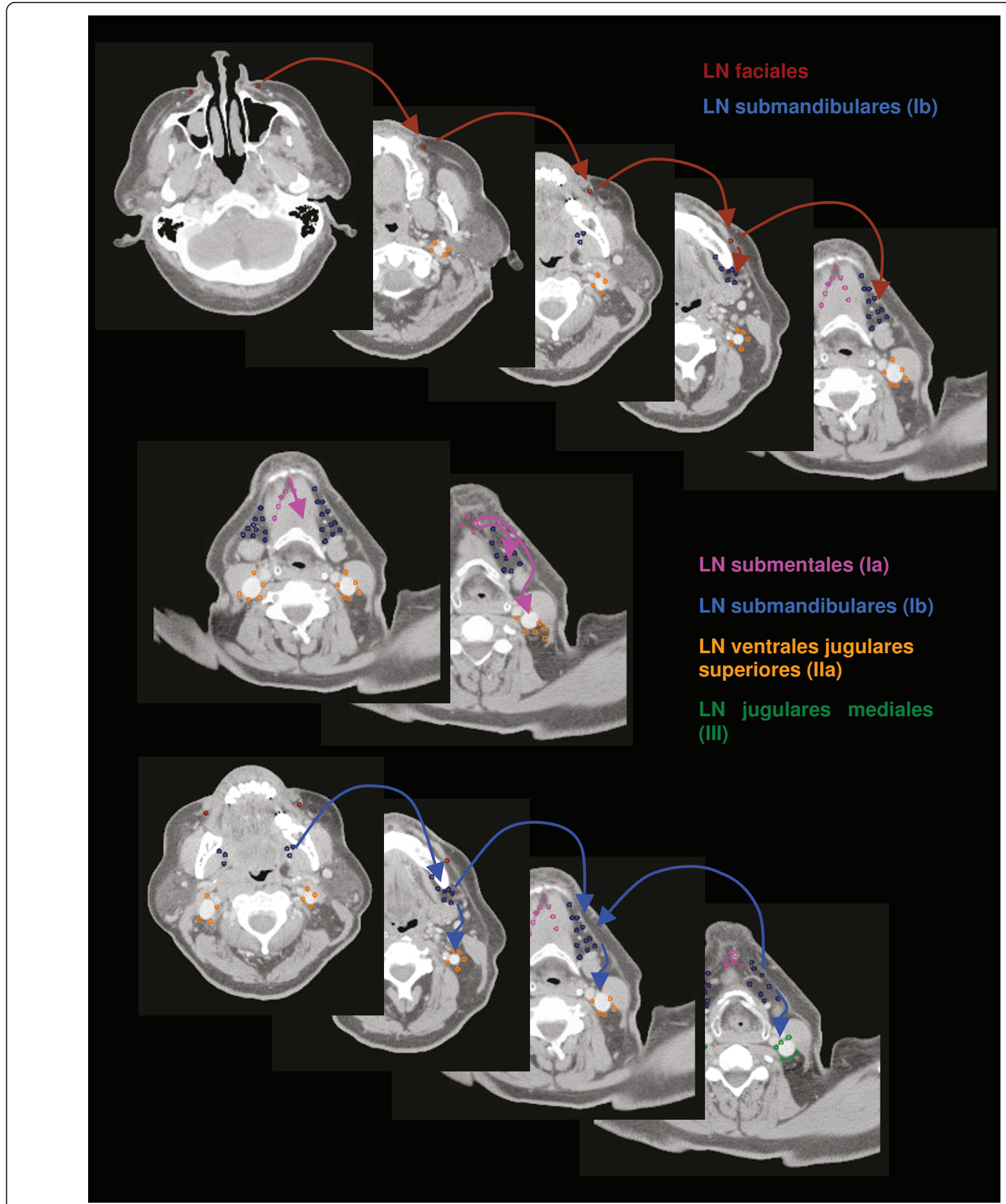

Figure 3 Lymph regions and drain contoured in transversal CT slices: LN buccales (brown), LN submentales (pink) and LN submandibulares (dark blue) $[1.8 \mathrm{~cm}$ slice thickness].

also to the level IIB (Table 5, 6). Tumors of the oral cavity, hypopharyngeal and laryngeal tumors are mainly associated to the level IIA and less to the level IIB [7].

- The incidence of metastatic lymph node involvement increases with the primary tumor size $[7,22,23]$.
- More factors, which influence the lymph node invasion, are the tumor differentiation, kertinization status, lymphatic vessel invasion in the tumor specimen, and whether other lymph node levels are involved [2]. Remmert et al. [22] found for example 


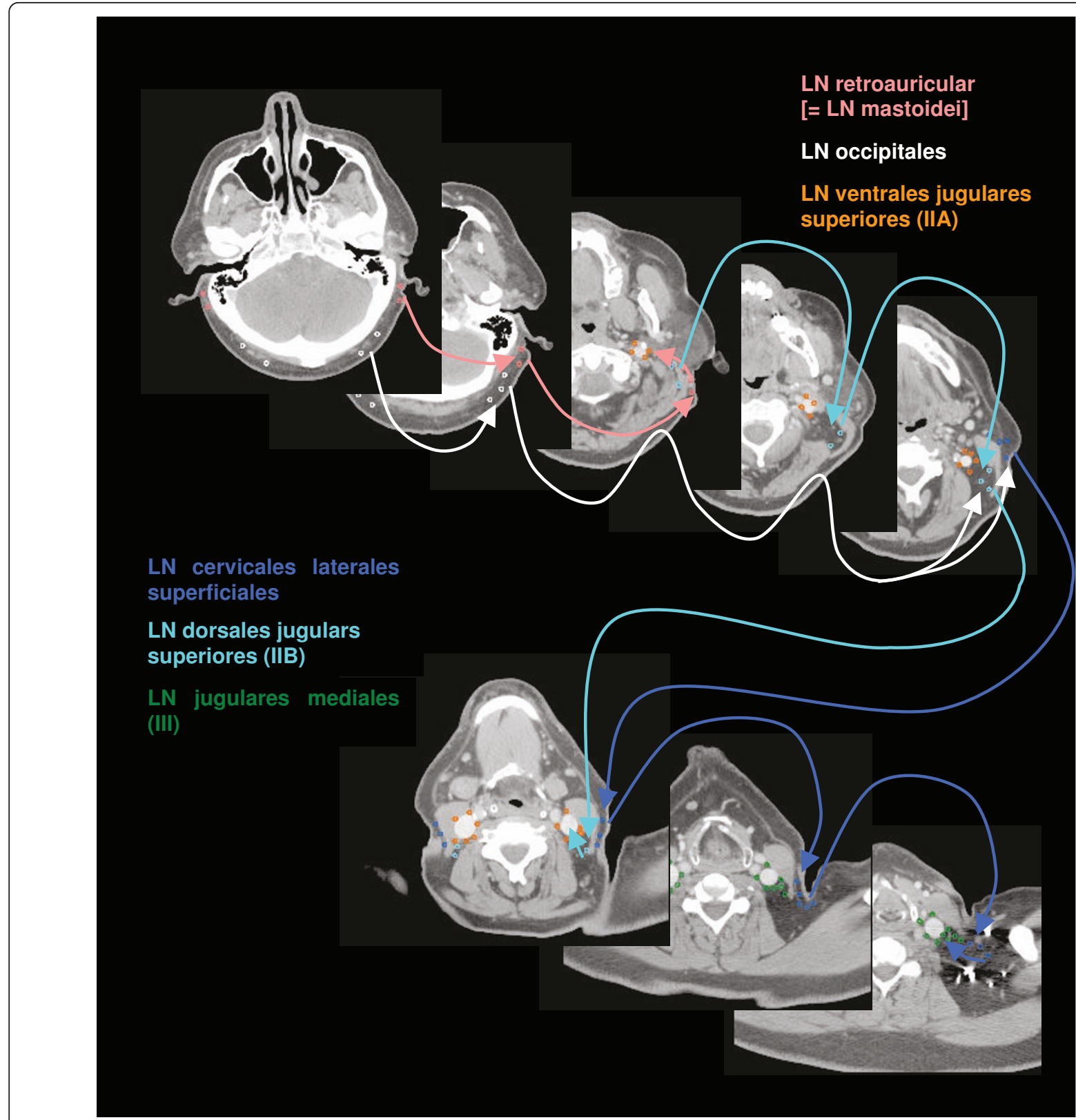

Figure 4 Lymph regions and drain contoured in transversal CT slices: LN occipitales (white), LN retroauriculares [ = LN mastoidei] (pink), LN cervicales laterales superficiales (medium blue) and LN dorsales jugulares superiores (cyan) [1.8 cm slice thickness].

16.7\% NM for G1 tumors, 36.5\% for G2 and 58.9\% for G3.

- If the tumor crosses the midline bilateral treatment of the LN is necessary [24].

The CTV of the lymph node regions should encompass all regions, who have a probability to contain NM of $10 \%$ or more [2,7]. If the NM infiltrates adjacent structures, the inclusion of this structure and the associated lymph drain in the CTV must individually be assessed [10].
Summarizing the highest incidence for over all NM can be found in patients with $\mathrm{cN}+$, a laryngeal cancer stage T3/4 and/or nasopharyngeal cancer $(\mathrm{cN}+)$. Patients with tumors of the oral cavity (even $\mathrm{cN}+$ or T3/4) have the lowest incidence for NM [7].

Clinical and pathologic neck node distributions support the concept, that not all lymph node level has to be treated for squamous cell tumors of the head and neck region [7]. All concepts base on retrospective data with possible bias because of mostly selected 


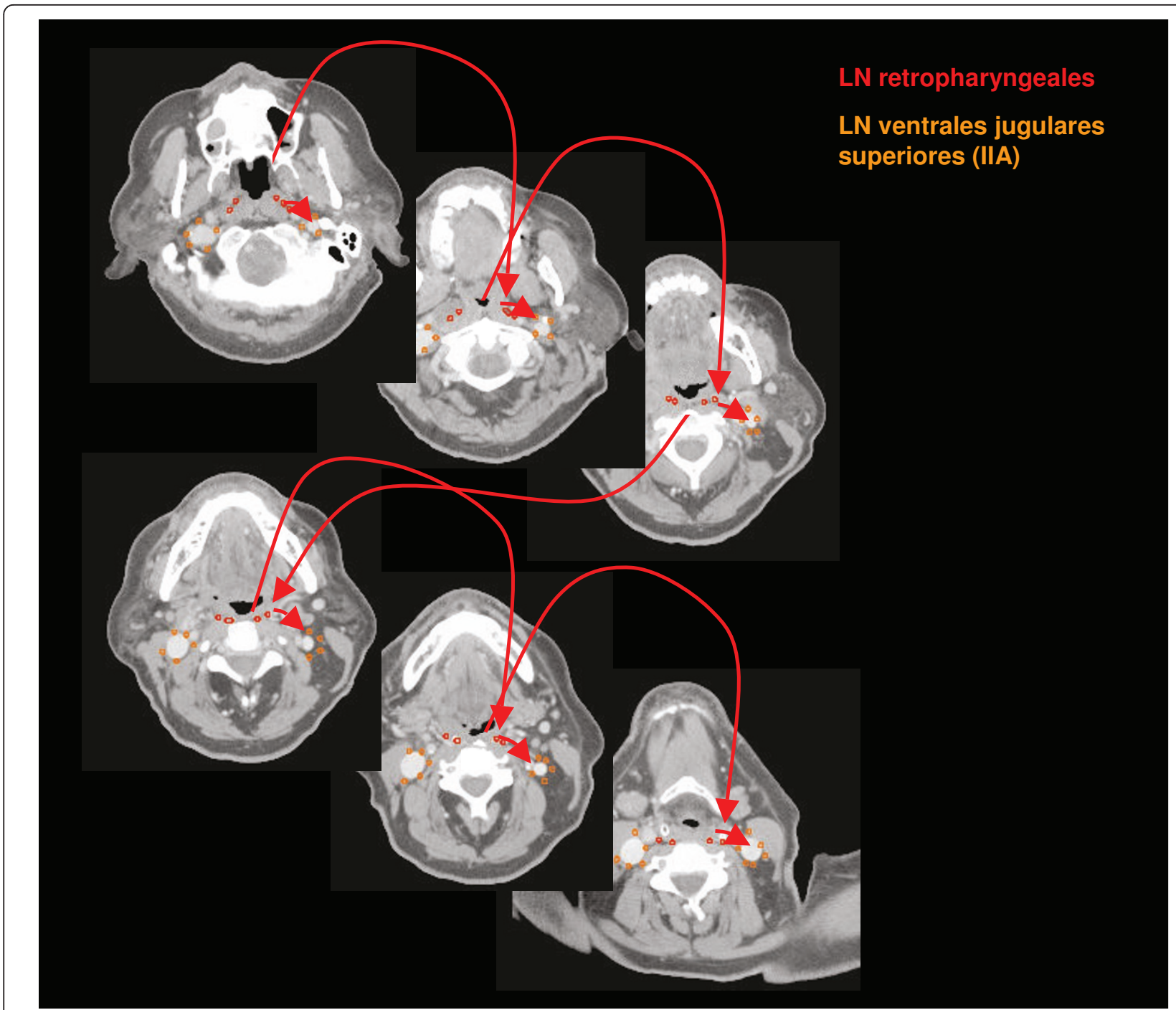

Figure 5 Lymph regions and drain contoured in transversal CT slices: LN retropharyngeales (red) [1 cm slice thickness]

patients. Some surgery techniques for the neck dissection do not perform lymph node dissection in all level, e.g. level IIb is often not examined, and will result in an underestimation of the involvement of these lymph node levels [7]. Another point is that the incidence of $\mathrm{NM}$ in retropharyngeal and paratracheal LN can only be estimated clinically. Medial retropharyngeal LN has been reported to be very rarely involved by radiologic analysis in contrast to the lateral retropharyngeal $\mathrm{LN}$ $[25,26]$. Therefore it seems to be adequate only to define the lateral retropharyngeal LN as target [27]. To exclude all these problems would require large multicenter randomized trials.

Both sides of the neck exhibit a similar pattern of node distribution, but with a lower incidence in the contralateral neck. There are only few data on the pattern of contralateral NM.
This must be assessed by recalculation of relative involvement probabilities to the subregions. The results are still more based on clinical judgment rather than from scientific evidence. Recalculated from the analysis of Gregoire et al. 2000 [7] more than 90\% of all NM are found on the ipsilateral side for tumors in the oral cavity or hypopharynx. Tumors of the oropharynx or larynx spread to the contralateral side in $11-14 \%$ of the patients. Only for tumors in the nasopharynx over $40 \%$ of the contralateral LN show metastases. The relative number of contralateral metastases must be correlated with the absolute number of pathologic LN per bilateral level to find the incidence per neck side. If the tumor invades the midline, the lymph drain to both sides of the neck and therefore both sides should be included in the CTV. Some anatomic regions have crossing lymph node drainage, like the soft palate, the tongue, the 


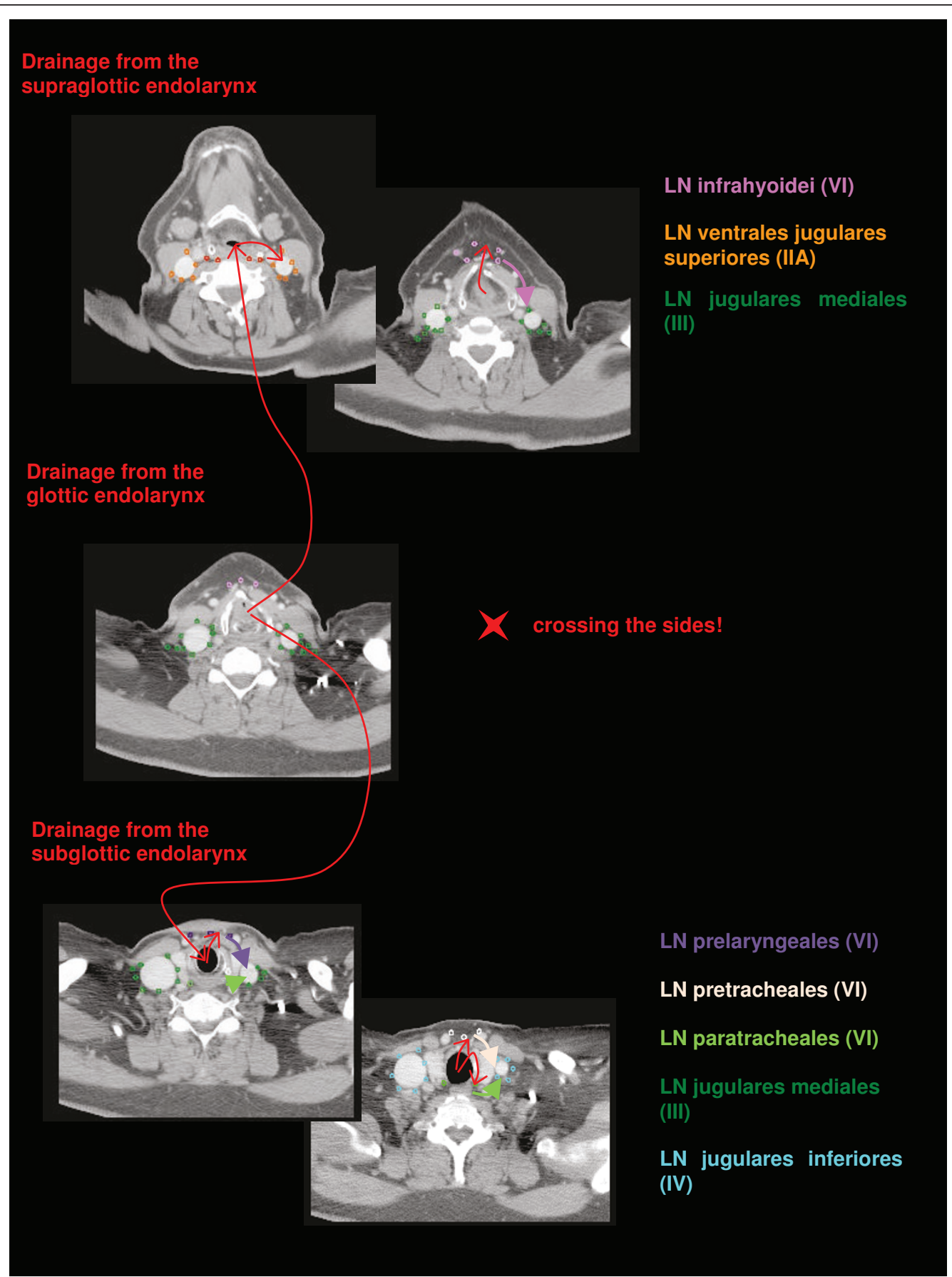

Figure 6 Lymph drainage from the endolarynx contoured in transversal CT slices (red arrows) to the LN infrahyoidei (pink), LN prelaryngeales (violet), LN pretracheales (light pink) and LN paratracheales (light green).

larynx and the nasopharynx [12]. But even for those tumors contralateral involvement occurs at a much lower frequency than on the ipsilateral side [7], but should also be included in the CTV (Table 4, 5, 6). As well is the incidence of retropharyngeal LN higher in $\mathrm{cN}$ + patients, in whom involvement of other neck node levels was also documented [7].
Infiltration of level $\mathrm{V}$ is very rare, except level IV is involved or more than a single lymph node in level I-III has metastatic disease (Table 4, 5, 6) $[7,20]$. Chone et al. [28] detected NM of level VA in pN0 patients with a prevalence of $2.3 \%$ and in $\mathrm{pN}+$ patients with $16.7 \%$. The prevalence was highest for tumors of the pharynx (23.1\%) in contrast to tumors of the oral cavity with 


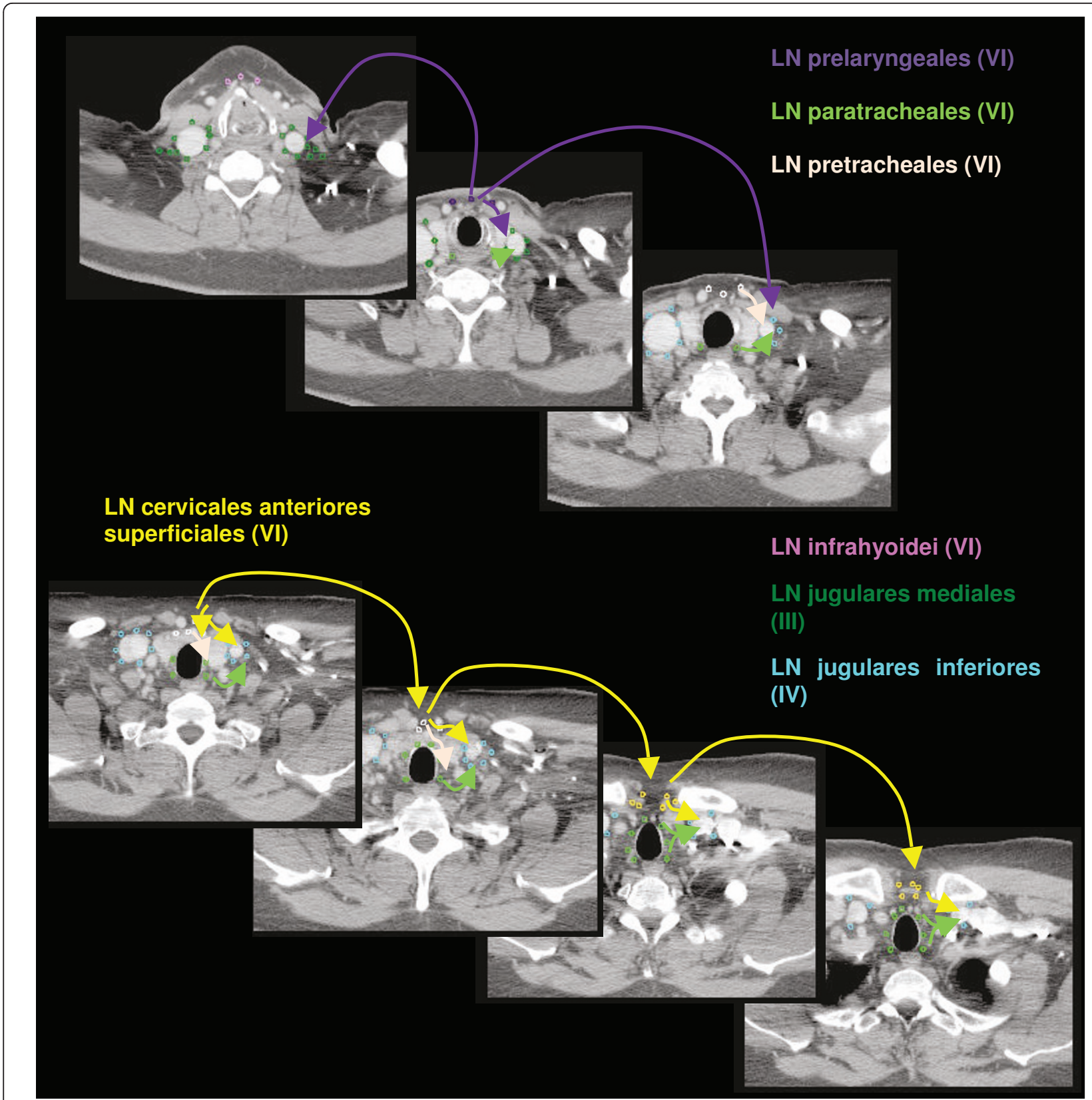

Figure 7 Lymph regions and drain contoured in transversal CT slices: LN cervicales anteriores superficiales (yellow) and LN cervicales anteriores profundi subdivided into LN infrahyoidei (pink), LN prelaryngeales (violet), LN pretracheales (light pink) and LN paratracheales (light green) $[1 \mathrm{~cm}$ slice thickness].

3.6\%. No NM were found for other tumor sides and there are no isolated metastases in level VA [28].

Timon at al. [3] found in patients with advanced cancer of the larynx, hypopharynx or cervical esophagus NM in $20 \%$ and $43 \%$ of the patients, respectively. $10 \%$ of the patients had positive paratracheal NM alone in a histopathological negative cervical neck dissection. In subglottic cancer the incidence of paratracheal NM can be up to $50 \%$ [7]. Therefore the LN paratracheal should be included in the CTV for patients with advanced laryngeal or hypopharyngeal tumors or extension of the tumor to the cervical esophagus.

Metastases are labelled as 'skip metastases', if the lymph node involvement bypass a lymph node level and involve the next but one level. Skip metastases are very rare [20]. Remmert et al. [22] analysed 405 patients with head and neck carcinoma and found no skip metastases. A series of the Head and Neck Service at Memorial 


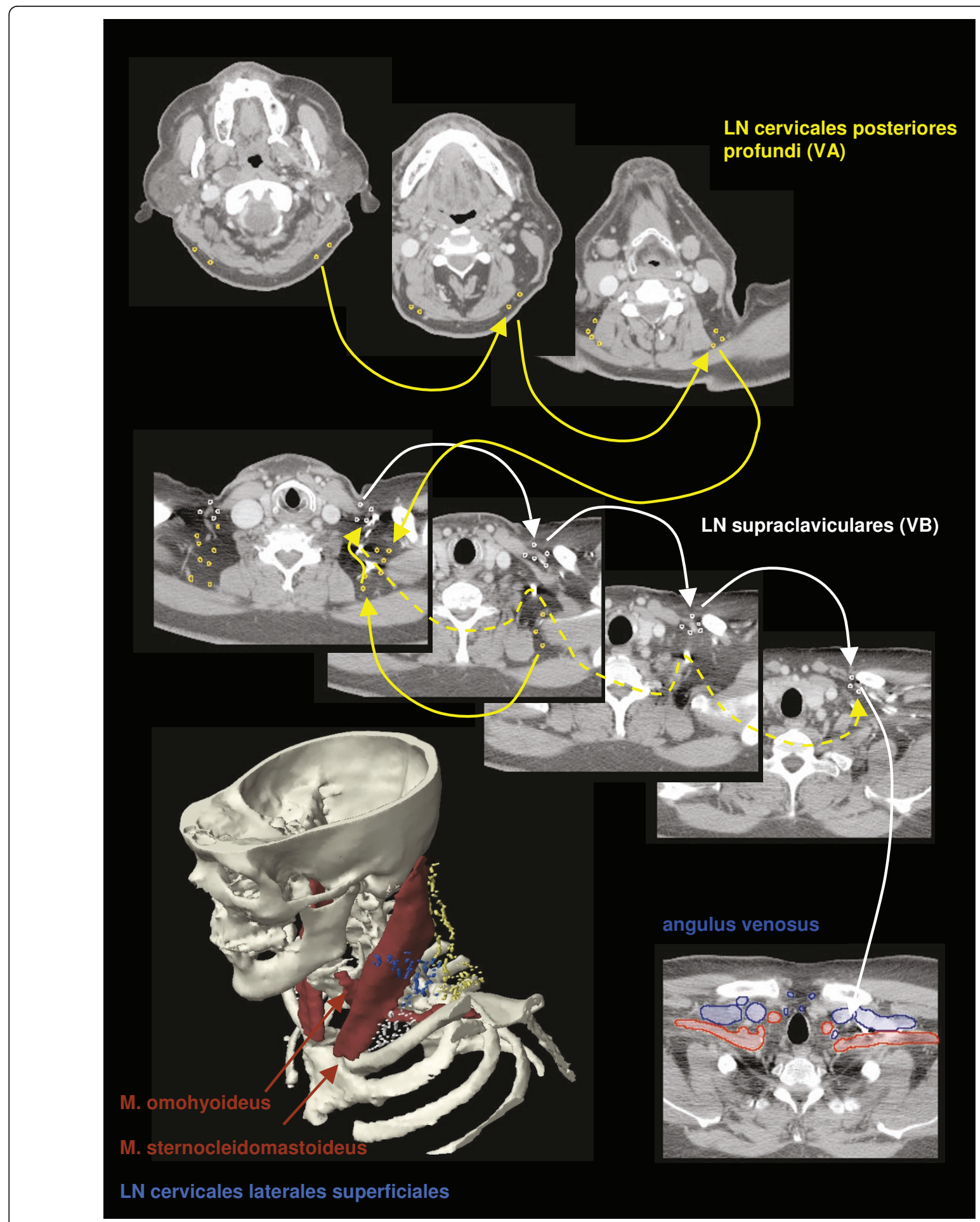

Figure 8 Lymph regions and drain contoured in transversal CT slices: LN cervicales posteriores profundi (yellow) and LN supraclaviculares (white).

Sloan-Kettering Cancer Center found skip metastases in $2.5 \%$ of the cN0 patients [7,23]. Only an analysis of tumors of the oral tongue by Byers et al. [29] reached a rate of $12 \%$ skip metastases in the level IIb, III and IV.

\section{Squamous cell cancer of the oral cavity}

The oral cavity itself has primary lymph drainage to the LN submandibulares and submentales (Table 1). Tumors of the tongue drain also directly to level IIA 
Table 4 Lymph node level (adapted to [17])

\begin{tabular}{|c|c|c|c|}
\hline Lymph node level & Terminology & Lymph node regions & Figure \\
\hline level IA & submental & LN submentales & 3 \\
\hline level IB & submandibular & LN submandibulares & 3 \\
\hline level IIA & ventral upper jugular group & LN ventrales jugulares superiores & $2-6$ \\
\hline level IIB & dorsal upper jugular group & LN dorsales jugulares superiores & 4 \\
\hline level III & mediales jugular group & LN jugulares mediales & $3-4,6-7$ \\
\hline level IV & lower jugular group & LN jugulares inferiores & 6 \\
\hline level VA & posterior triangle group & LN cervicales posteriors profundi & 8 \\
\hline level VB & posterior triangle group & LN supraclaviculares & 8 \\
\hline \multirow[t]{7}{*}{ level VI } & anterior compartment & LN cervicales anteriores superficiales & 6 \\
\hline & & LN cervicales anteriores profundi: & 7 \\
\hline & & - LN infrahyoidales & \\
\hline & & - LN prelaryngeales & \\
\hline & & - LN pretracheales & \\
\hline & & - LN paratracheales & \\
\hline & & - LN thyroidei & \\
\hline level retropharyngeal & retropharyngeal & LN retropharyngeales & 5 \\
\hline \multirow[t]{2}{*}{ level parotidal } & parotidal & LN parotidei superficiales & 2 \\
\hline & & LN parotidei profundi & \\
\hline level retroauricular & retroauricular & LN retroauriculares & 4 \\
\hline level occipital & occipital & LN occipitales & 4 \\
\hline level buccal & buccal & LN faciales & 3 \\
\hline level external jugular & external jugular & LN cervicales laterales superficiales & 4 \\
\hline
\end{tabular}

and III $[6,30]$. The lymph from the hard palate and upper gingiva flows additionally to the LN retropharyngeales. Squamous cells tumors of the oral cavity have the lowest absolute incidence of NM of all head and neck regions, but the overall incidence of $\mathrm{NM}$ for $\mathrm{N}+$ patients is still high with more than $30 \%[7,22,24,31]$. In level IIA, II and III the relative incidence of NM is higher than $10 \%$, independent of the tumor location $[6,7]$. These levels should be included in the lymphatic CTV (Table 5). The general probability for contralateral NM is low with $<10 \%$ [6]. But the lymph drainage of the tongue has direct significant cross-over with a higher risk of contralateral NM $[6,7,32]$. And the hard palate and upper gingiva have additional lymph drain to the LN retropharyngeales of both sides [7]. Yen et al. [33] found for patients with squamous cell carcinoma of the buccal mucosa a high incidence of NM in the ipsilateral level I to III. Patients with this tumor entity showed only $2 \%$ contralateral NM, why it is reasonable only to treat the ipsilateral side $[16,33]$.

Robbins et al. [18] has suggested that for N0 patients no elective lymph node dissection of level IIB is necessary [24]. Analogically the level IIB may not be included in the CTV for patients with N0. Byers et al. [29] found a high incidence of NM in level IV in patients with tumors of the (ventral) tongue, which should therefore be included in the CTV, even for N0 patients [24]. Shah et al. [23] described a prevalence of NM in level IV of $3 \%$ in patients underwent elective node dissection and $17 \%$ in patients with therapeutic neck dissection, wherefore this level should be included in the CTV for all $\mathrm{N}+$ patients of the oral cavity. Oral cavity carcinoma in cN0 patients nearly never metastasizes to level V, which therefore may not be included in the CTV [24]. The incidence for NM in the parotidal LN in patients with oral squamous cell carcinoma is very rare $(2.5 \%)$ with about 75\% intraglandular NM [34].

\section{Squamous cell cancer of the oropharynx}

The overall incidence of NM is over $60 \%$ for squamous cell tumors of the oropharynx $[6,7,30]$. The primary drainage of the tongue base is to level II and III of both sides [6]. An analysis of tumors of the oral tongue by Byers et al. [29] reached a rate of $12 \%$ skip metastases in the level IV, for which reason this level should be included in the lymphatic CTV (Table 5). The lymphatic drainage of the tonsil is mainly to level IIA, without crossing the sides $[6,12,30]$. Certainly histopathologic evaluation showed level I (and also level V) involvement only in association with involvement of other levels $(\mathrm{N}+$ disease) [20]. Tumors of the soft palate and dorsal pharyngeal wall show NM on both sides via crossing lymph 
Table 5 Suggested guidelines for the treatment of the neck of patients with squamous cell carcinoma of the oral cavity or oropharynx

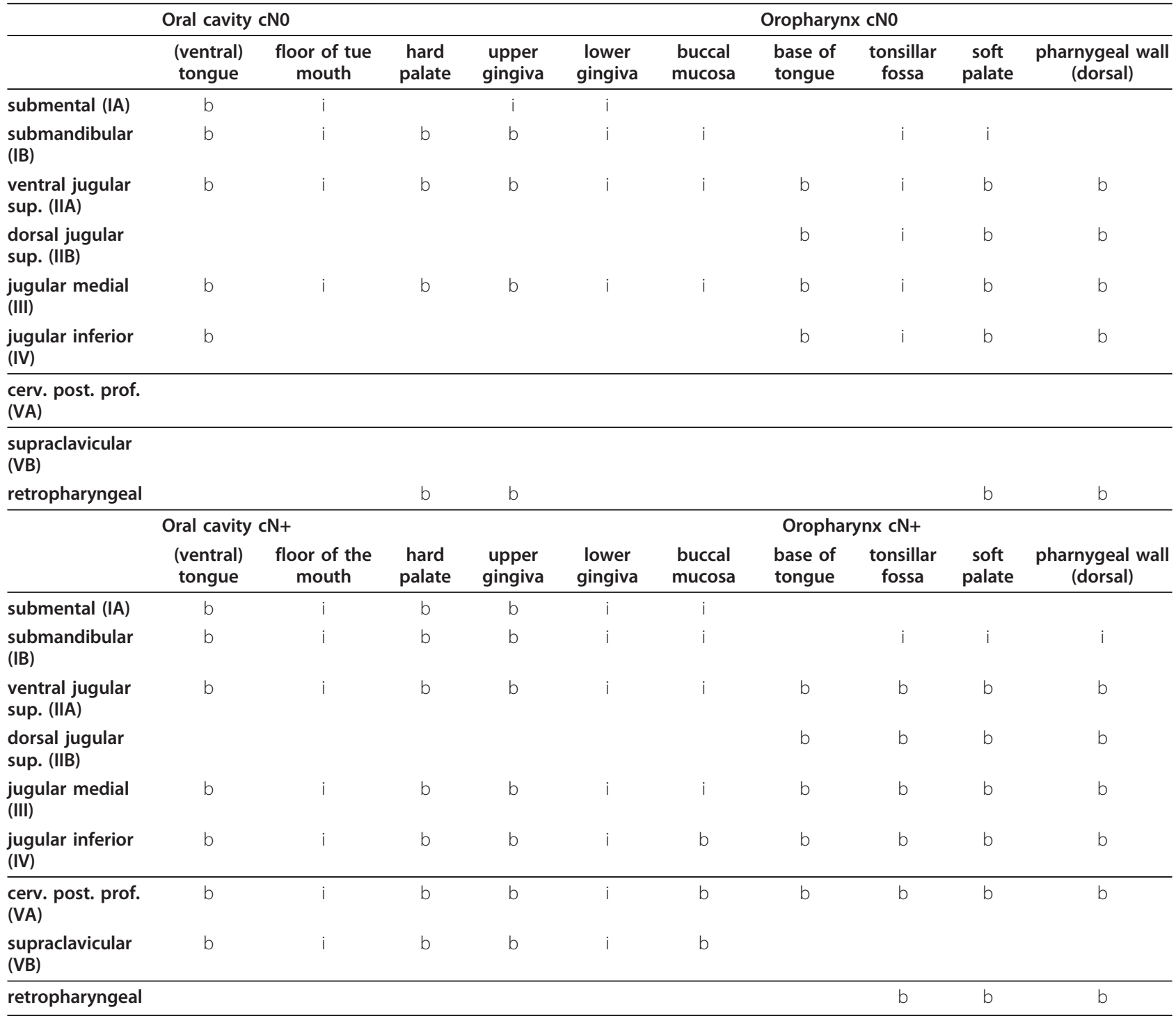

vessels $[6,7,12]$. For these tumors the retropharyngeal LN should be included in the CTV $[7,35]$.

\section{Squamous cell cancer of the hypopharynx}

The lymphatic drain of the piriform sinus is to the LN paratracheales and directly to the level III $[6,12,30]$. The pharyngeal wall has additional efflux to the LN retropharyngeal and the ipsilateral LN prelaryngeales, pretracheales and infrahyoidei. The overall incidence for NM in patients with tumors of the hypopharynx is very high with over $70 \%[7,22]$. The number of reported detected contralateral NM is low $(<10 \%)$, but should not be neglected because of the anatomic cross-lymphatic drainage of the hypopharyngeal region [6]. The LN cervicales anteriores profundi (Figure 6, 7), included in level
VI, drain lymph not only from the hypopharynx, larynx and thyroid gland, but also from the cervical trachea and upper esophagus [7]. The incidence of pathologic $\mathrm{LN}$ in this region is reported rarely. Therefore in the case of tumor infiltration of the cervical trachea or the upper esophagus respectively the level VI should be included in the CTV (Table 6). All hypopharyngeal tumors has a high probability of ipsilateral paratracheal NM, for which reason this region should be included in the CTV $[3,7,36]$. As for patients with tumors of the oral cavity the level IIb must not be included in the CTV for patients with N0 as suggested by Robbins et al. [18]. Histopathologic evaluation showed level I involvement for tumors of the pharyngeal wall in association with involvement of other levels $(\mathrm{N}+$ disease) [20]. The 
Table 6 Suggested guidelines for the treatment of the neck of patients with squamous cell carcinoma of the hypopharynx, larynx or nasopharynx

\begin{tabular}{|c|c|c|c|c|c|c|c|c|}
\hline & \multicolumn{3}{|c|}{ Hypopharynx cNO } & \multicolumn{4}{|l|}{ Larynx cNO } & \multirow{2}{*}{$\begin{array}{c}\text { Nasopharynx } \\
\text { cNO }\end{array}$} \\
\hline & $\begin{array}{l}\text { pyriform } \\
\text { sinus }\end{array}$ & $\begin{array}{l}\text { pharyngeal } \\
\text { wall }\end{array}$ & $\begin{array}{l}\text { esophageal } \\
\text { extension }\end{array}$ & supraglottic & glottic & subglottic & $\begin{array}{c}\text { posterior } \\
\text { part }\end{array}$ & \\
\hline \multicolumn{9}{|l|}{ submental (IA) } \\
\hline \multicolumn{9}{|l|}{ submandibular (IB) } \\
\hline $\begin{array}{l}\text { ventral jugular sup. } \\
\text { (IIA) }\end{array}$ & $b$ & $b$ & $\mathrm{~b}$ & $b$ & $b$ & i & i & $b$ \\
\hline $\begin{array}{l}\text { dorsal jugular sup. } \\
\text { (IIB) }\end{array}$ & & & & & & & & $b$ \\
\hline jugular medial (III) & $b$ & $b$ & $b$ & $b$ & $b$ & $b$ & $b$ & $b$ \\
\hline jugular inferior (IV) & $\mathrm{b}$ & $b$ & $\mathrm{~b}$ & $\mathrm{~b}$ & $\mathrm{~b}$ & $b$ & $\mathrm{~b}$ & $b$ \\
\hline cerv. post. prof. (VA) & & & $b$ & & & & & $\mathrm{~b}$ \\
\hline supraclavicular (VB) & & & $b$ & & & & & $b$ \\
\hline infrahyoidal (VI) & & i & i & $b$ & $\mathrm{~b}$ & & & \\
\hline prelaryngeal (VI) & & $\mathrm{i}$ & $\mathrm{i}$ & & $b$ & $b$ & & \\
\hline pretracheal (VI) & & i & i & & $\mathrm{b}$ & $b$ & & \\
\hline paratracheal (VI) & i & i & i & & $\mathrm{b}$ & $b$ & $b$ & \\
\hline retropharyngeal & & $b$ & $\mathrm{~b}$ & & & & & $b$ \\
\hline \multirow{2}{*}{\multicolumn{9}{|c|}{$\begin{array}{l}\text { faciales } \\
\text { parotidal }\end{array}$}} \\
\hline & & & & & & & & \\
\hline & \multicolumn{2}{|c|}{ Hypopharynx cN+ } & & Larynx cN+ & & & & $\begin{array}{c}\text { Nasopharynx } \\
\mathrm{cN}+\end{array}$ \\
\hline & $\begin{array}{l}\text { pyriform } \\
\text { sinus }\end{array}$ & $\begin{array}{l}\text { pharyngeal } \\
\text { wall }\end{array}$ & $\begin{array}{l}\text { esophageal } \\
\text { extension }\end{array}$ & supraglottic & glottic & subglottic & $\begin{array}{c}\text { posterior } \\
\text { part }\end{array}$ & \\
\hline submental (IA) & & $b$ & & & & & & \\
\hline submandibular (IB) & & $\mathrm{b}$ & & & & & & $b$ \\
\hline $\begin{array}{l}\text { ventral jugular sup. } \\
\text { (IIA) }\end{array}$ & $b$ & $b$ & $\mathrm{~b}$ & $b$ & $\mathrm{~b}$ & i & $b$ & $b$ \\
\hline $\begin{array}{l}\text { dorsal jugular sup. } \\
\text { (IIB) }\end{array}$ & & & & & & & & $b$ \\
\hline jugular medial (III) & $b$ & $b$ & $\mathrm{~b}$ & $b$ & $\mathrm{~b}$ & $b$ & $b$ & $b$ \\
\hline jugular inferior (IV) & $\mathrm{b}$ & $b$ & $b$ & $b$ & $\mathrm{~b}$ & $\mathrm{~b}$ & $\mathrm{~b}$ & $b$ \\
\hline cerv. post. prof. (VA) & $b$ & $\mathrm{~b}$ & $\mathrm{~b}$ & & $\mathrm{~b}$ & $\mathrm{~b}$ & $\mathrm{~b}$ & $\mathrm{~b}$ \\
\hline supraclavicular (VB) & $b$ & $b$ & $b$ & & $b$ & $b$ & $b$ & $b$ \\
\hline infrahyoidal (VI) & i & i & i & $b$ & $b$ & & & \\
\hline prelaryngeal (VI) & i & i & i & & $b$ & $b$ & & \\
\hline pretracheal (VI) & i & i & i & & $b$ & $b$ & & \\
\hline paratracheal (VI) & i & i & i & & $\mathrm{b}$ & $b$ & $\mathrm{~b}$ & \\
\hline retropharyngeal & $\mathrm{b}$ & $\mathrm{b}$ & $\mathrm{b}$ & & & & & $\mathrm{b}$ \\
\hline faciales & & & & & & & & $\mathrm{b}$ \\
\hline parotidal & & & & & & & & $b$ \\
\hline
\end{tabular}

prevalence of level V NM is only in $\mathrm{N}+$ patients high enough to encompass this region in the CTV [20]. For all tumors of the pharyngeal wall the retropharyngeal LN should be included in the CTV [7].

\section{Squamous cell cancer of the larynx}

The lymphatic drainage of the larynx is different for the supraglottic and subglottic region (Figure 6). The supraglottic endolarynx drains to level IIA, LN infrahyoidei and level II, whereas the subglottic endolarynx drains to level VI (especially LN prelaryngeales, pretracheales, paratracheales) and level IV (Table 6). The glottic region has few lymph vessels, which drain to both regions $[6,12-14,21,30]$. The reported overall incidence for NM varies between $26 \%$ and $55 \%$ [7,22]. Especially the supraglottic larynx has a rich lymphatic drainage, resulting in a high incidence of occult cervical metastases [37]. The number of occult NM is about 20\% [4,21]. Even the 
Table 7 Suggested guidelines for the treatment of the neck of patients with squamous cell carcinoma in the head and neck region

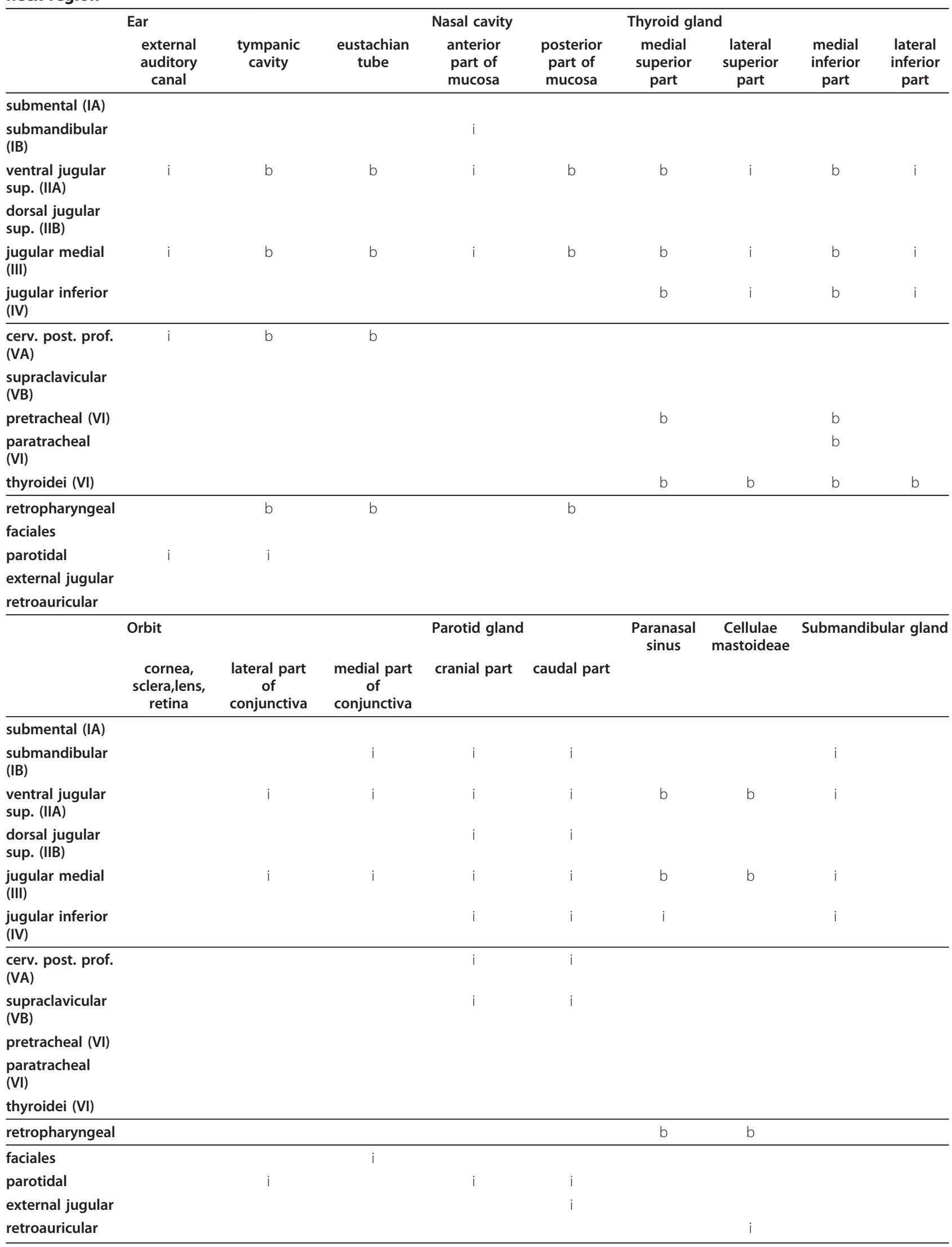


Table 8 Suggested guidelines for the treatment of the neck of patients with carcinomas of the skin

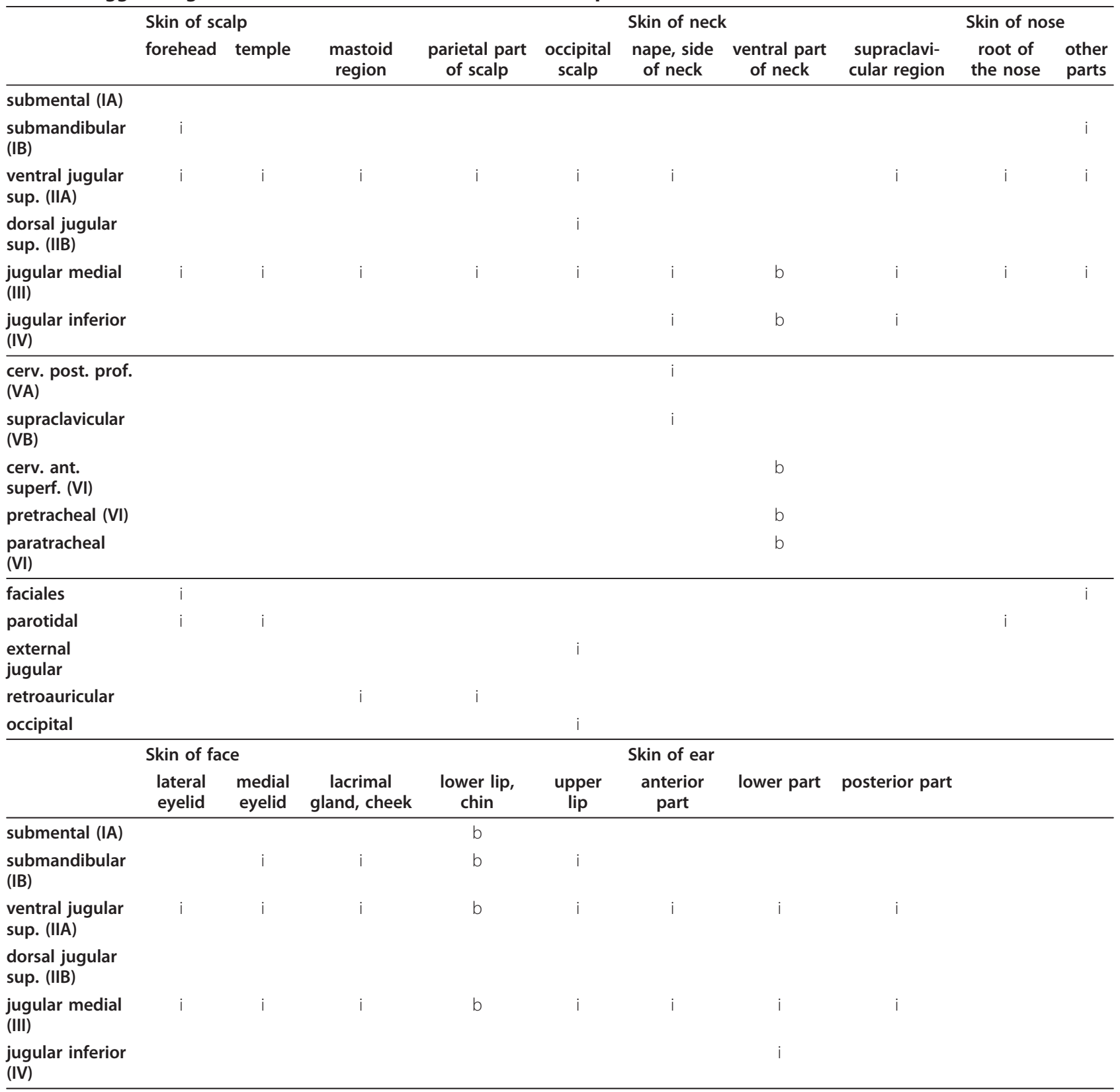

(IV)

cerv. post. prof.

(VA)

supraclavicular

(VB)

cerv. ant.

superf. (VI)

pretracheal (VI)

paratracheal

(VI)

faciales

parotidal

external

jugular

retroauricular

occipital 


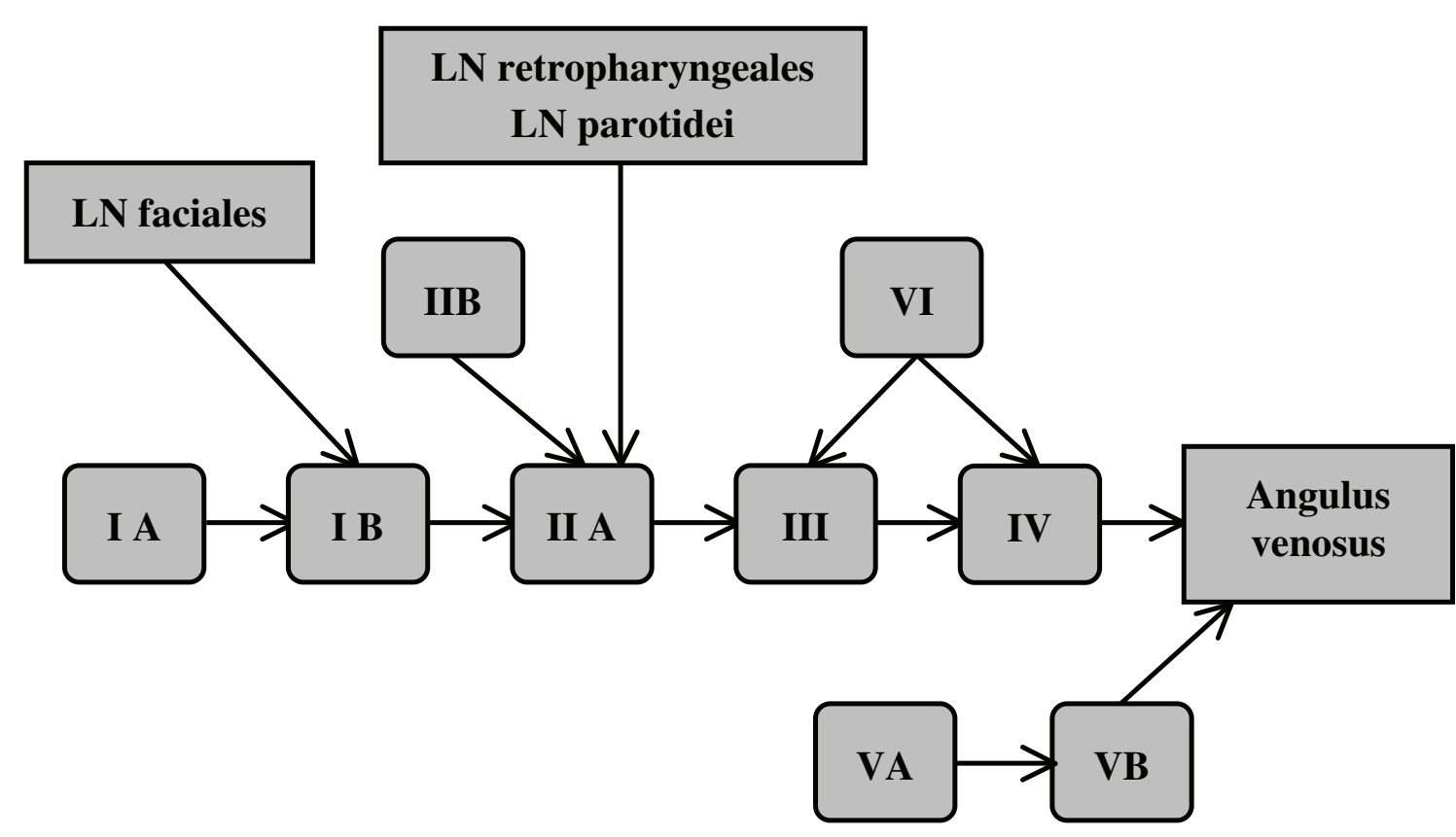

Figure 9 Schematic scheme of main direction of lymph node flow in the head and neck region.

glottic region has few lymph vessels; the number of NM for advanced tumors adds up to $32 \%$ [21]. The number of NM in level II, III and IV is very high for all laryngeal cancers $[4,6,22,38]$. Especially supraglottic tumors are at risk for crossed lymphatic drainage. The mechanism by which this occurs is still debatable [6]. As for patients with tumors of the larynx the level IIb must not be included in the CTV for patients with N0 as suggested by Robbins et al. [18]. Laryngeal tumors has a high probability of paratracheal NM, especially tumors with subglottic extension, for which reason this region should be included in the CTV $[3,7,36]$. Even for $\mathrm{N}+$ patients the involvement of level $\mathrm{I}$ is very rare and can be omitted [7,38].

\section{Squamous cell cancer of the nasopharynx}

The lymphatic vessels drain mainly to the $\mathrm{LN}$ retropharyngeales, level IIA and VA. Inconsistent channels can drain to the LN parotidales $[6,30]$. Squamous cell tumors of the nasopharynx show a very high rate of $\mathrm{NM}$ in $80 \%$ of the patients [7]. Even for N0 patients the incidence of NM in the bilateral level IIA, IIB, III, IV, VA and VB is high and should be included in the lymphatic CTV (Table 6) [6,7,39]. The lymph vessels in the retropharyngeal region are often crossing the sides. Accordingly the number of contralateral NM (30\%) is very high in patients with nasopharyngeal cancer $[6,7,35]$ and should be included in the lymphatic CTV.

\section{Other tumors of the head and neck region}

The distribution of cervical NM from primary parotidal carcinoma is rarely reported. Hence there is no consensus as to which extent the cervical level should be irradiated. Chrisholm et al. [40] found in the ipsilateral level I to $\mathrm{V}$ more than $20 \% \mathrm{NM}$ each. Therefore all these level should be encompassed in the CTV (Table 7).

Squamous cell carcinomas in other location in the head and neck regions are rarely reported and all present analyses bases on small patient groups. Our suggested guidelines contribute mostly on anatomic lymph drain and medical experience. Because of the high overall incidence $(<30 \%)$ of ipsilateral NM in squamous cell cancer of the maxilla, treatment of the ipsilateral neck should be considered even in cases with a negative clinical examination [41,42] (Table 7). Patients with auricular squamous cell carcinoma present NM in $10 \%-30 \%$ of the cases [43-45]. Clark et al. [44] found, that the parotid gland was the commonest side of node metastases, followed by LN retroauriculares and level II, III and V (Table 7). For the treatment of thyroid carcinoma the level II, II and IV show a high incidence of NM [46].

\section{Tumors of the skin}

The curative treatment of basal cell carcinoma and squamous cell carcinoma with N0 status mostly includes no treatment of the lymph node regions because of insufficient evidence [47]. For patients with clinical or histological affected lymph nodes the CTV should 


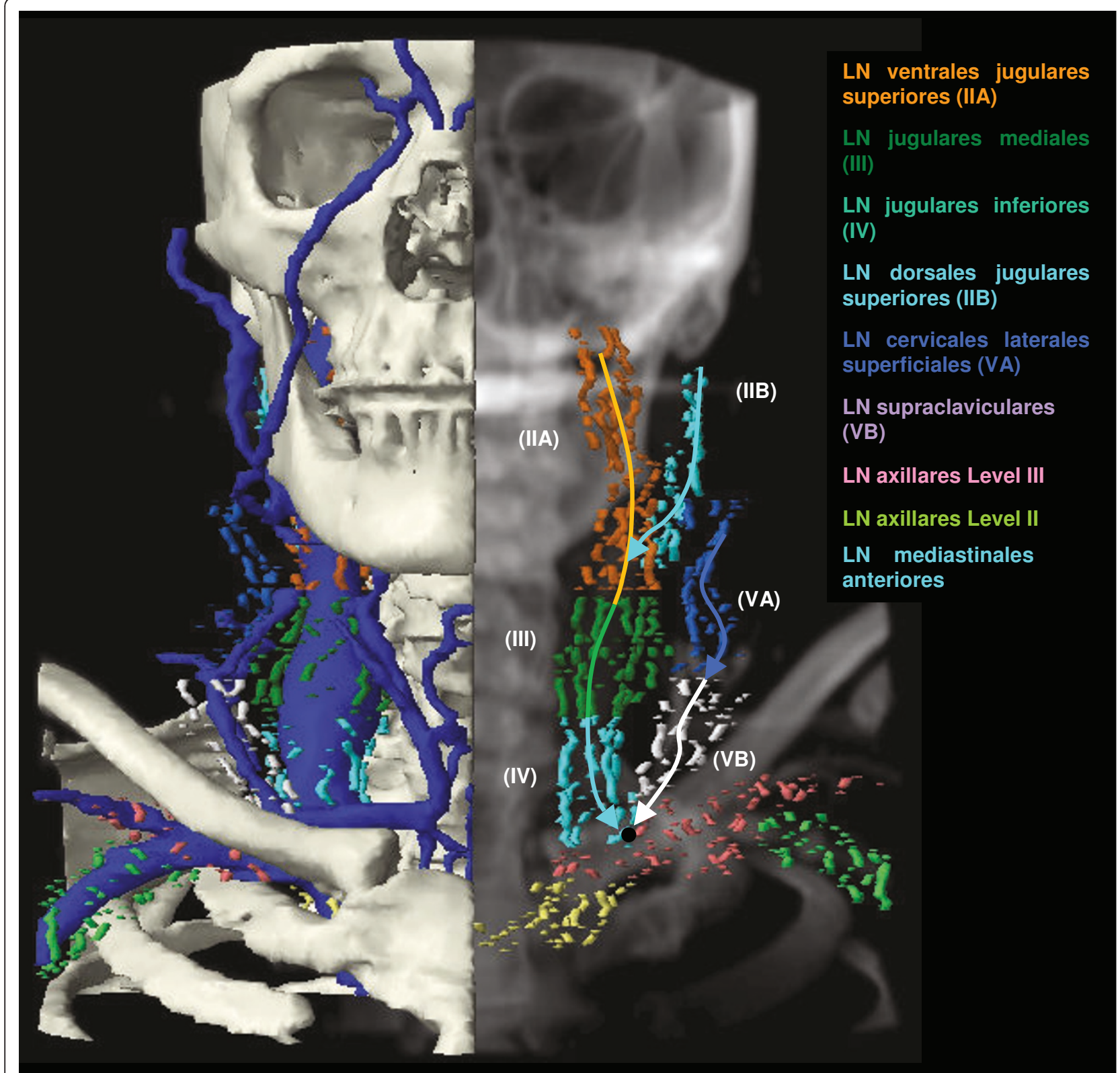

Figure 10 Coronar DRR with different lymph node regions, bones and veins. The black circle symbolises the angulus venosus.

encompass the lymph node regions listed in Table 8, but at least the affected lymph node region with one additional region. For melanomas the affected lymph node region and two additional regions should be encompassed in the lymphatic CTV. The lymph from the medial eyelid drains to the LN submandibulares and LN faciales, whereas the lymph from the lateral eyelid drains to the LN parotidei profundi and superficiales (Table 8, Figure 11) [12]. The lymph of the upper lip flows to the LN submandibulares and the lymph of the lower lip flows also to the LN submentales with possible crossing of the sides. The anterior parts of the ear drain to the preauriculares, the lower parts to the LN cervicales laterales superficiales and the posterior parts to the retroauriculares $\mathrm{LN}$. The lymph vessels of the forehead and temple run to the $\mathrm{LN}$ parotidei superficiales and the lymph vessels of the parietal part of the scalp to the LN retroauriculares. The occipital scalp is drained by the LN occipitales. The dorsal and lateral neck regions have outflow to the LN cervicales posteriors profundi as well as to LN cervicales laterales superficiales. The lymph of the ventral parts of the neck flows to $\mathrm{LN}$ cervicales 


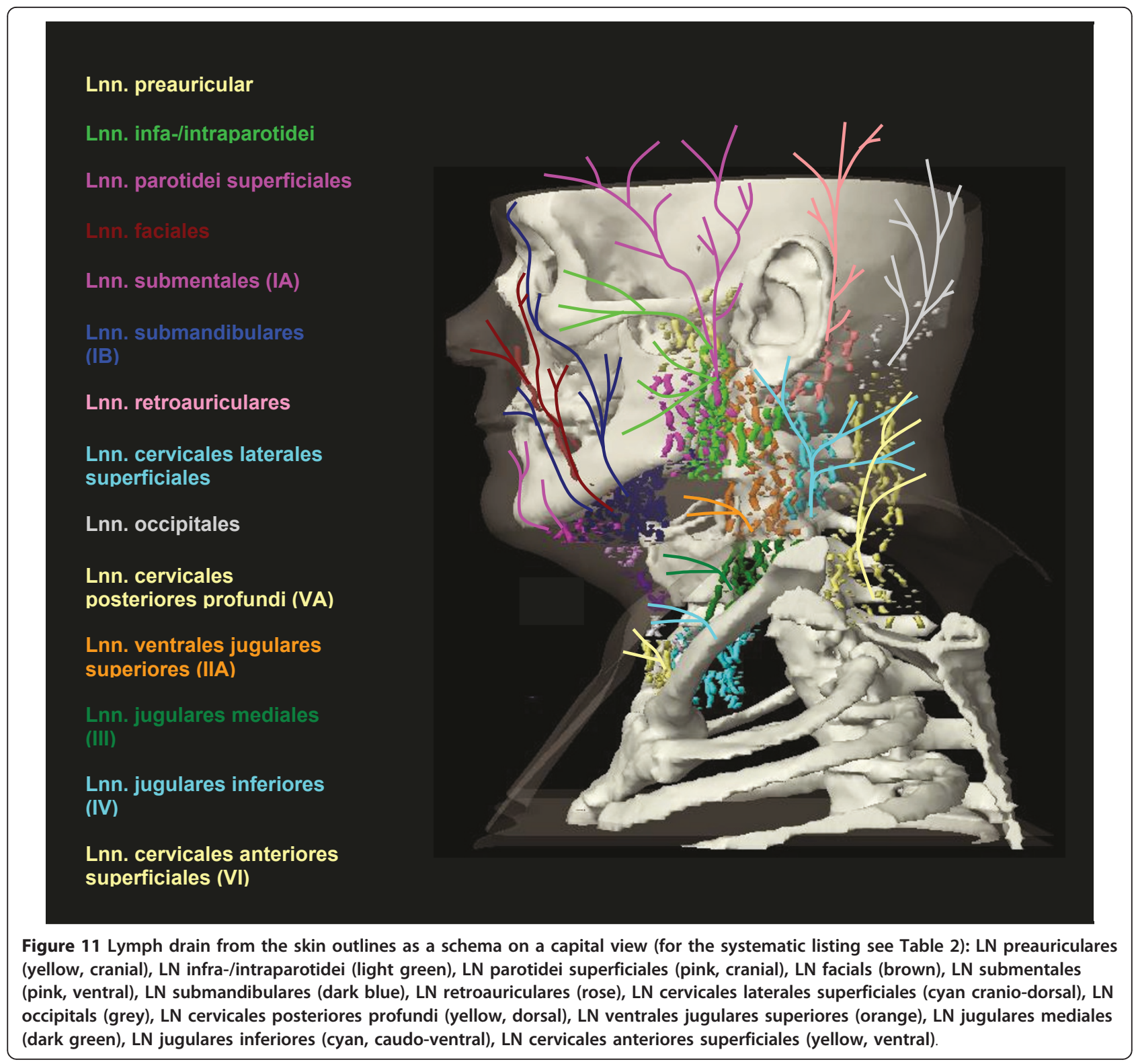

anteriores superficiales and forwards to the LN pre- and paratracheales. The skin of the supraclavicular region drains to LN jugulares.

\section{Conclusions}

We have reviewed the expected lymphatic drainage of different parts of the head and neck region and correlated this with the current used level system and histopathologic experience. The results are contoured on various $\mathrm{CT}$ slices and summarized in Table 5, 6, 7, 8 .

\section{Acknowledgements}

These guidelines do not intend to give any recommendation for the optimal treatment strategy. Physician will have to weigh available data on patterns of lymph node infiltration for various locations, grad and extent of the primary, organ infiltration, probability of treatment morbidity, extent of NM etc. The review did not analyse the post-operative situation.

\section{Author details}

'Radiotherapy and Radiooncology, University Hospital Göttingen, RobertKoch-Str. 40, 37073 Göttingen, Germany. ${ }^{2}$ Radiotherapy and Radiooncology, University Marburg, Baldingerstrasse, 35043 Marburg, Germany.

\section{Authors' contributions}

HV carried out the literature review, performed the statistical analysis and the typing. CFH participated in the design and coordination of the analysis and the writing of the manuscript. All authors read and approved the final manuscript.

\section{Competing interests}

The authors declare that they have no competing interests.

Received: 14 April 2011 Accepted: 19 August 2011

Published: 19 August 2011 


\section{References}

1. Keberle M, Ströbel P, Marx A, Hahn D, Hoppe F: CT determination of lymphocytic infiltration around head and neck squamous cell carcinomas may be a predictor of lymph node metastases. Eur Arch Otorhinolaryngol 2003, 260:558-564

2. Eisbruch A, Foote RL, O'Sullivan B, Beitler JJ, Vikram B: Intensity-modulated radiation therapy for head and neck cancer: emphasis on the selection and delineation of the targets. Semin Radiat Oncol 2002, 12:238-249.

3. Timon CV, Toner M, Conlon BJ: Paratracheal lymph node involvement in advanced cancer of the larynx, hypopharynx, and cervical esophagus. Laryngoscope 2003, 113:1595-1599.

4. Gallo O, Deganello A, Scala J, De Campora E: . Evolution of elective neck dissection in N0 laryngeal cancer. Acta Otorhinolaryngol Ital 2006, 26:335-344.

5. Lengelé $B$, Hamoir M, Scalliet $P$, Grégoire $V$ : Anatomical bases for the radiological delineation of lymph node areas. Major collecting trunks, head and neck. Radiother Oncol 2007, 85:146-155.

6. Mukherji SK, Armao D, Joshi VM: Cervical nodal metastases in squamous cell carcinoma of the head and neck: what to expect. Head Neck 2001, 23:995-1005.

7. Grégoire V, Levendag P, Ang KK, Bernier J, Braaksma M, Budach V, Chao C, Coche E, Cooper JS, Cosnard G, Eisbruch A, El-Sayed S, Emami B, Grau C, Hamoir M, Lee N, Maingon P, Muller K, Reychler H: CT-based delineation of lymph node levels and related CTVs in the node-negative neck: DAHANCA, EORTC, GORTEC, NCIC, RTOG consensus guidelines. Radiother Oncol 2003, 69:227-236

8. RTOG contouring atlases. [http://www.rtog.org/atlases/contour.html].

9. Grégoire V, Coche E, Cosnard G, Hamoir M, Reychler H: Selection and delineation of lymph node target volumes in head and neck conformal radiotherapy. Proposal for standardizing terminology and procedure based on the surgical experience. Radiother Oncol 2000, 56:135-150.

10. Grégoire V, Eisbruch A, Hamoir M, Levendag P: Proposal for the delineation of the nodal CTV in the node-positive and the postoperative neck. Radiother Oncol 2006, 79:15-20.

11. International Commission on Radiation Units and Measurements. Prescribing, recording and reporting photon beam therapy. ICRU Report 50 Washington DC: International Comission on radiation Units and Measurement; 1993.

12. Richter E, Feyerabend T: Normal lymph node topography. Springer Verlag 1991.

13. Frick h, Leonhardt H, Starck D: Spezielle Anatomie I. Thieme Verlag 1987.

14. Frick h, Leonhardt H, Starck D: Spezielle Anatomie II. Thieme Verlag 1987.

15. Martinez-Monge R, Fernandes PS, Gupta N, Gahbauer R: Cross-sectional nodal atlas: a tool for the definition of clinical target volumes in threedimensional radiation therapy planning. Radiology 1999, 211:815-828.

16. Woolgar JA: Histological distribution of cervical lymph node metastases from intraoral/oropharyngeal squamous cell carcinomas. $\mathrm{Br} J \mathrm{Oral}$ Maxillofac Surg 1999, 37:175-180.

17. Som PM, Curtin HD, Mancuso AA: An imaging-based classification for the cervical nodes designed as an adjunct to recent clinically based nodal classifications. Arch Otolaryngol Head Neck Surg 1999, 125:388-396.

18. Robbins KT: Classification of neck dissection: current concepts and future considerations. Otolaryngol Clin North Am 1998, 31:639-655.

19. Robbins KT, Medina JE, Wolfe GT, Levine PA, Sessions RB, Pruet CW: Standardizing neck dissection terminology. Offcial report of the Academy's committee for head and neck surgery and oncology. Arch Otolaryngol Head Neck Surg 1991, 117:601-605.

20. Candela FC, Kothari K, Shah JP: Patterns of cervical node metastases from squamous carcinoma of the oropharynx and hypopharynx. Head Neck 1990, 12:197-203.

21. Waldfahrer $\mathrm{F}$, Hauptmann B, Iro H: Lymph node metastasis of glottic laryngeal carcinoma. Laryngorhinootologie 2005, 84:96-100.

22. Remmert S, Rottmann M, Reichenbach M, Sommer K, Friedrich HJ: Lymph node metastasis in head-neck tumors. Laryngorhinootologie 2001, 80:27-35.

23. Shah JP: Patterns of cervical lymph node metastasis from squamous carcinomas of the upper aerodigestive tract. Am J Surg 1990, 160:405-409.

24. Ferlito $A$, Silver $C E$, Rinaldo A: Elective management of the neck in oral cavity squamous carcinoma: current concepts supported by prospective studies. Br J Oral Maxillofac Surg 2009, 47:5-9.
25. Poon I, Fischbein N, Lee N, Akazawa P, Xia P, Quivey J, Phillips T: A population-based atlas and clinical target volume for the head-and-neck lymph nodes. Int J Radiat Oncol Biol Phys 2004, 59:1301-1311.

26. Bussels B, Hermans R, Reijnders A, Dirix P, Nuyts S, Van den Bogaert W: Retropharyngeal nodes in squamous cell carcinoma of oropharynx: incidence, localization, and implications for target volume. Int J Radiat Oncol Biol Phys 2006, 65:733-738.

27. Feng FY, Kim HM, Lyden TH, Haxer MJ, Feng M, Worden FP, Chepeha DB, Eisbruch A: Intensity-modulated radiotherapy of head and neck cancer aiming to reduce dysphagia: early dose-effect relationships for the swallowing structures. Int J Radiat Oncol Biol Phys 2007, 68:1289-1298.

28. Chone CT, Crespo AN, Rezende AS, Carvalho DS, Altemani A: Neck lymph node metastases to the posterior triangle apex: evaluation of clinical and histopathological risk factors. Head Neck 2000, 22:564-571.

29. Byers RM, Weber RS, Andrews T, McGill D, Kare R, Wolf P: Frequency and therapeutic implications of "skip metastases" in the neck from squamous carcinoma of the oral tongue. Head Neck 1997, 19:14-19.

30. Rouviere $\mathrm{H}$, Tobias MJ: Anatomy of the human lymphatic system. Ann Arbor: Edwards 1938.

31. Montes DM, Carlson ER, Fernandes R, Ghali GE, Lubek J, Ord R, Bell B, Dierks E, Schmidt BL: Oral maxillary squamous carcinoma: An indication for neck dissection in the clinically negative neck. Head Neck

32. González-García R, Naval-Gías L, Sastre-Pérez J, Rodríguez-Campo FJ, MuñozGuerra MF, Usandizaga JL, Díaz-González FJ: Contralateral lymph neck node metastasis of primary squamous cell carcinoma of the tongue: a retrospective analytic study of 203 patients. Int J Oral Maxillofac Surg 2007, 36:507-513.

33. Yen TC, Chang JT, Ng SH, Chang YC, Chan SC, Wang HM, See LC, Chen TM, Kang CJ, Wu YF, Lin KJ, Liao CT: Staging of untreated squamous cell carcinoma of buccal mucosa with 18F-FDG PET: comparison with head and neck CT/MRI and histopathology. J Nucl Med 2005, 46:775-781.

34. Harada H, Omura K: Metastasis of oral cancer to the parotid node. Eur Surg Oncol 2009, 35:890-894.

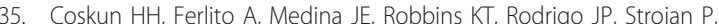
Suárez C, Takes RP, Woolgar JA, Shaha AR, de Bree R, Rinaldo A, Silver CE: Retropharyngeal lymph node metastases in head and neck malignancies. Head Neck 2010.

36. de Bree $R$, Leemans $C R$, Silver CE, Robbins KT, Rodrigo JP, Rinaldo A Takes RP, Shaha AR, Medina JE, Suárez C, Ferlito A: Paratracheal lymph node dissection in cancer of the larynx, hypopharynx, and cervical esophagus: The need for guidelines. Head Neck 2011, 33:912-916.

37. Alpert TE, Morbidini-Gaffney S, Chung CT, Bogart JA, Hahn SS, Hsu J, Kellman RM: Radiotherapy for the clinically negative neck in supraglottic laryngeal cancer. Cancer J 2004, 10:335-338.

38. dos Santos CR, Gonçalves Filho J, Magrin J, Johnson LF, Ferlito A Kowalski LP: Involvement of level I neck lymph nodes in advanced squamous carcinoma of the larynx. Ann Otol Rhinol Laryngol 2001, 110:982-984

39. Liu LZ, Zhang GY, Xie CM, Liu XW, Cui CY, Li L: Magnetic resonance imaging of retropharyngeal lymph node metastasis in nasopharyngeal carcinoma: patterns of spread. Int J Radiat Oncol Biol Phys 2006, 66:721-730.

40. Chisholm EJ, Elmiyeh B, Dwivedi RC, Fisher C, Thway K, Kerawala C, Clarke PM, Rhys-Evans PH: Anatomic distribution of cervical lymph node spread in parotid carcinoma. Head Neck 2011, 33:513-515.

41. Cantù G, Bimbi G, Miceli R, Mariani L, Colombo S, Riccio S, Squadrelli M, Battisti A, Pompilio M, Rossi M: Lymph node metastases in malignant tumors of the paranasal sinuses: prognostic value and treatment. Arch Otolaryngol Head Neck Surg 2008, 134:170-177.

42. Kruse AL, Grätz KW: Cervical metastases of squamous cell carcinoma of the maxilla: a retrospective study of 9 years. Head Neck Oncol 2009, 1:28.

43. Clark RR, Soutar DS: Lymph node metastases from auricular squamous cell carcinoma. A systematic review and meta-analysis. J Plast Reconstr Aesthet Surg 2008, 61:1140-1147.

44. Clark RR, Soutar DS, Hunter KD: A retrospective analysis of histological prognostic factors for the development of lymph node metastases from auricular squamous cell carcinoma. Histopathology 2010, 57:138-146.

45. Lobo D, Llorente JL, Suárez C: Squamous cell carcinoma of the external auditory canal. Skull Base 2008, 18:167-172. 
46. Hwang HS, Orloff LA: Efficacy of preoperative neck ultrasound in the detection of cervical lymph node metastasis from thyroid cancer. Laryngoscope 2011, 121:487-491.

47. Veness MJ: High-risk cutaneous squamous cell carcinoma of the head and neck. J Biomed Biotechnol 2007, 2007:80572.

doi:10.1186/1748-717X-6-97

Cite this article as: Vorwerk and Hess: Guidelines for delineation of

lymphatic clinical target volumes for high conformal radiotherapy: head and neck region. Radiation Oncology 2011 6:97.

Submit your next manuscript to BioMed Central and take full advantage of:

- Convenient online submission

- Thorough peer review

- No space constraints or color figure charges

- Immediate publication on acceptance

- Inclusion in PubMed, CAS, Scopus and Google Scholar

- Research which is freely available for redistribution

Submit your manuscript at www.biomedcentral.com/submit 